\title{
Exercise tolls the bell for key mediators of low-grade inflammation in dysmetabolic conditions
}

\author{
Lucio Della Guardiaa, Roberto Codella ${ }^{a, b}$ \\ a Department of Biomedical Sciences for Health, Università degli Studi di Milano, Milano, Italy \\ b Department of Endocrinology, Nutrition and Metabolic Diseases, IRCCS MultiMedica, Milano, Italy
}

\author{
Corresponding author \\ Roberto Codella, Ph.D. \\ Department of Biomedical Sciences for Health \\ Università degli Studi di Milano \\ Via Fratelli Cervi 93, 20090 Segrate (Milano) \\ Telephone: +39-02-50330356 \\ E-mail: roberto.codella@unimi.it
}

Abbreviations:

AGEs, advanced glycation end-products; AKT, Protein kinase B; AMPK, AMP-activated protein kinase; BAT, brown adipose tissue; BDNF, brain-derived neurotrophic factors; CRP, C-reactive protein FFAs, fatty Free acids; GLUT4: glucose transporter 4; HFD, High fat diet; IL-1 $\beta$, interleukin 1 Beta; IL-10, interleukin 10; IL-6; Interleukin 6; IL-1ra, Interleukin 1 receptor antagonist; IRS, insulin receptor substrates. JNK 1-2, c-Jun nterminal kinases 1 and 2; LPS: lipopolysaccharide; MCP-1, macrophage chemotactic protein 1; METRNL, meteorin-like protein; NF-kB, nuclear factor kappa-light-chain-enhancer of activated B cells; P38MAPK, P38 mitogen-activated protein kinases; PGC-1 Peroxisome proliferator-activated receptor gamma coactivator 1alpha; PPAR, peroxisome proliferator-activated receptor; RAGE, Receptor of advanced glycation end-products; SOCS3, suppressor of cytokine signaling 3; T2D, type 2 diabetes; TLR, toll-like receptor. TNFa: tumoral necrosis. UCP-1: uncoupling protein-1. 


\begin{abstract}
Metabolic conditions share a common low-grade inflammatory milieu, which represents a key-factor for their ignition and maintenance. Exercise is instrumental for warranting systemic cardio-metabolic balance, owing to its regulatory effect on inflammation. This review explores the effect of physical activity in the modulation of sub-inflammatory framework characterizing dysmetabolic conditions.

Regular exercise efficaciously suppresses plasma levels of TNF $\alpha$, IL-1 $\beta$, FFAs and MCP-1, in dysmetabolic subjects. The increased levels of IL-10, IL-1 receptor antagonist (IL-1ra), and muscle-derived IL-6 contribute to lower the sub-inflammatory state. Resting IL-6 levels are decreased in trained-dysmetabolic subjects. On the other hand, the acute release of muscle-IL- 6 seems to exert a regulatory effect on the metabolic and inflammatory balance. In fact, muscle-released IL- 6 is presumably implicated in fat loss and boosts plasma levels of IL-10 and IL-1ra. The improvement of adipose tissue functionality, following regular exercise, is also critical for the mitigation of sub-inflammation. This effect is likely mediated by muscle-IL-15 and IL- 6 and partly relies on the browning-inducing activity of exercise. In obese-dysmetabolic subjects, training is shown to restore gut-microbiota health and this mitigates the translocation of bacterial-LPS into bloodstream. Finally, regular exercise can lower plasma advanced glycated end-products. The articulate physiology of circulating mediators and the modulating effect of the pathophysiological background, render the comprehension of the exercise-regulatory effect on sub-inflammation a key issue, in dysmetabolism.
\end{abstract}

\title{
Keywords
}

Physical activity, cytokines, skeletal muscle, insulin resistance, adipose tissue, immune cells.

\section{Introduction}

A variety of factors comprising environmental agents, gut-microbiota health and nutrition concur to determine whole-body metabolic balance. Persistent states of inflammation in conditions, like chronic inflammatory diseases, negatively impact on systemic insulin sensitivity leading to the increased risk of developing type 2 diabetes (T2D) and other cardio-metabolic disturbances [1]. Circulating pro-inflammatory mediators form a molecular network capable of regulating glucometabolic balance, representing the connection between inflammation and metabolic disturbances [2]. Low-grade inflammation is defined as a subtle increase of circulating pro-inflammatory cytokines [2]. Growing evidence demonstrates that chronic low-grade inflammation is instrumental in the development and progression of chronic metabolic conditions [3-5]. Conversely, pharmacological mitigation of sub-inflammatory background is capable to re-establish glucometabolic homeostasis [6-8]. At the organ level, cytokines allow the communication between resident cells as to ensure on-site inflammatory stability and tissue correct functionality [9]. Systemically, organokines and cytokines are instrumental for mediating the signaling between tissues and regulating immune system cells trafficking and activation. On the other side, they regulate key pathways modulating inflammatory balance and insulin sensitivity in targeted tissues [9].

Dysmetabolic conditions including insulin resistance, T2D and metabolic syndrome are typically associated with physical inactivity, incorrect dietary habits and obesity [9-11]. Untrained skeletal muscles of obesedysmetabolic individuals express an inflammatory diabetogenic phenotype, which influences systemic inflammatory balance [9]. In obesity and T2D, white adipose tissue releases pro-inflammatory mediators affecting gluco-metabolic homeostasis by altering liver and muscle functionality [2,9]. On the other hand, in trained subjects, the energy substrates turnover is optimized, and an array of muscle-released biomolecules act positively on the inflammatory milieu [2]. In this perspective, physical activity can represent a suitable strategy for the prevention and/or treatment of a range of metabolic diseases and conditions associated with systemic inflammation [12-15]. 
This review considers the cardio-metabolic protection offered by exercise through its anti-inflammatory and immune-modulatory effects.

\section{Exercise modulates the network of mediators implicated in low-grade inflammation}

It is unclear whether inflammation represents a predisposing factor rather than a consequence of metabolic disturbances $[16,17]$. Exogenous factors such as physical activity, nutrition and environmental determinants modulate tissues' functionality and the pattern of circulating mediators, influencing the degree of systemic inflammation $[2,18]$. Moderate exercise is often associated with reduction in markers systemic low-grade systemic inflammation [19], circulating leukocytes [20] and it is currently seen as a viable strategy to improve metabolic status in chronic inflammatory and cardiovascular diseases $[13,19]$. Exercise exerts its regulatory activity on low-grade inflammation by i) lowering the pro-inflammatory state secondary to sedentariness induced by untrained muscles and adipose tissue dysfunction ii) stimulating muscle secretion of active metabolites impacting on glucometabolic/inflammatory homeostasis; iii) ameliorating the functionality of tissues involved in metabolic/inflammatory regulation. IV) restoring euglycemia. All these determinants are reciprocally influencing within a highly interconnected network.

\section{Adipose tissue-muscle crosstalk in inactive subjects promotes low-grade inflammation}

Low cardiorespiratory fitness and physical inactivity are associated with a higher prevalence of cardiovascular diseases and increased mortality rates among individuals with dysmetabolic disturbances [21]. Physical inactivity represents the background condition leading to adipose tissue expansion and functional impairment $[21,22]$.

Adipose tissue stores the energy surplus in the form of triglycerides (TGC) [18]. In addition, it functions as a crucial metabolic regulator [18]. An array of molecules mediate the crosstalk of adipose tissue with brain, liver and muscles, coordinating an intricate network regulating whole-body inflammatory/metabolic balance $[9,18,23]$. The optimization of TGC storage, in adipose tissue, is critical for the maintenance of a correct metabolic homeostasis $[18,24,25]$. Physical inactivity and nutrition excess enhance TGC storage. Adipocytes TGC accumulation over a certain threshold activate intracellular stress- apoptosis pathways conductive to inflammation. Such changes lead to adipose tissue inflammation and dysfunction [18,24]. The tight interplay between adipocytes and resident macrophages contributes to impair adipose tissue function and fosters the shifting toward a pro-inflammatory cytokine pattern (i.e., IL-6, TNF $\alpha$, FFAs, MCP-1) [18,23]. The spillage of adipocyte- and macrophage-released mediators from adipose tissue into systemic circulation is strongly implicated in the development of systemic low-grade inflammation [18].

Untrained muscles have probably an active role in determining the systemic metabolic and inflammatory status in sedentary-obese subjects $[9,21,26,27]$. In obesity and T2D, myocytes become dysfunctional and produce proinflammatory cytokines in response to increased circulating FFAs challenge $[26,28]$. In healthy adults, muscle unloading during bed-rest studies has been associated with a muscle tissue shifting toward a pro-inflammatory phenotype (figure 1) [29,30]. The basal activity of nuclear transcriptional factor NF-KB activity was found to be higher in both obese/non-diabetic and T2D subjects compared to healthy lean control $[30,31]$. Like other tissues, skeletal muscle harbors different resident immune cells, which augment in pathological conditions [9]. Recent evidence shows an accumulation of macrophages within muscles, in obesesedentary and T2D individuals [9,26,32]. Interestingly, the accumulation of macrophages is positively correlated with BMI and the degree of systemic insulin resistance [26,27], suggesting that adipose tissue dysfunction in obesity probably influences muscle inflammatory homeostasis and vice versa (figure 1). This last finding is corroborated by the augmented TNFa expression in skeletal muscles of sedentary obese/insulinresistant subjects [26]. Of note, intra-muscular TNF $\alpha$ overexpression seems to be only dependent on muscle- 
resident macrophages [26]. These findings underpin that muscle inflammation, secondary to obesity and inactivity, may have a role in the development of systemic insulin resistance [33]. Inflamed muscles of inactive subjects show less insulin sensitivity and may contribute to alter whole-body metabolic/inflammatory balance by decreasing gluco-lipidic clearance [9,34]. It is also presumable that the pro-inflammatory shifting in phenotype and secretome in sedentariness/obesity, might enhance systemic sub-inflammation $[26,32,35]$. On the contrary, the practice of continuous exercise potentially reverts this condition (figure 1).

\section{Exercise-regulated mediators improve metabolic homeostasis}

The practice of constant exercise positively influences the pro-inflammatory background in cardio-metabolic conditions (figure 1). Part of this modulating activity is attributable to a variety of muscle-released cytokines and metabolites, during or after exercise [36]. Different investigations demonstrate how trained muscles release molecules with autocrine, paracrine, or endocrine activity, potentially influencing the systemic inflammatory background $[2,34,36]$. Metabolites released by myocytes and muscle-resident immune cells, in response to physical activity, play an active role in the amelioration of insulin sensitivity, lipids oxidation and adipocyte differentiation (table 1 ).

\subsection{Exercise uncovers a metabolic-regulatory activity of IL-6}

Circulating levels of IL- 6 are strongly associated with chronic inflammatory diseases and cardio-metabolic disorders [37,38]. IL-6 activates the suppressor of cytokine signaling 3 (SOCS3), which inhibits cell insulin signaling [39]. High levels of IL-6 in dysmetabolic subjects induce hyperinsulinemia, glucose intolerance $[40,41]$ and insulin resistance in skeletal muscle [42]. Adipose tissue-derived IL-6 can suppress hepatic insulin sensitivity and promotes hepatic steatosis [39,40,43,44].

The effect of exercise on IL-6 levels suggests a multimodal activity of the cytokine, mainly depending on site of secretion and pathophysiological context (table 1). This would also be consistent with recent insights highlighting a homeostatic role of IL- 6 rather than an exclusive pro-inflammatory/diabetogenic activity $[45,46]$. For example, some evidence suggests that IL- 6 can act as a driver for TH2 lymphocytes and M 2 macrophages polarization, in obesity [47]. In addition, IL-6 signalling, in hepatocytes and in macrophages, mitigates systemic inflammation and ameliorates glucose balance [48].

Empirical evidence demonstrates that exercise induces an acute increase of IL-6 $[36,49,50]$. Noteworthy, this is most likely beneficial for gluco-metabolic health. In healthy subjects, the acute infusion of IL-6 at concentrations, mimicking post-exercise levels, was shown to enhance GLUT-4 translocation and improve insulin sensitivity in skeletal muscle [51]. Exercise-induced IL-6 has been shown to stimulate glucagon-like peptide-1 secretion from intestinal L-cells and pancreatic B-cells [46]. Exercise-induced muscle-IL-6 targets adipose tissue [52] where stimulates lipolysis and the loss of adipose mass [45,52]. Conversely, the knockout of IL-6 [53] or the blockage of IL-6 signaling [45] blunts the lipolytic effect of exercise [45,53]. Similarly, the ameliorating effect of exercise on hepatic steatosis is suppressed upon IL-6 knock-out [53]. Other insights support a potential anti-inflammatory effect of the exercise-induced IL-6 release. Indeed, an acute dose of IL- 6 stimulates the production of the anti-inflammatory IL-10 and IL-receptor antagonist (IL-1ra) in humans [50,54]. TNF $\alpha$ levels decrease upon exercise-induced increase of IL-6 [36]. Both the exogenous infusion of IL-6 and the ergometer cycling, in healthy subjects, are capable to inhibit endotoxin-driven upregulation of TNF $\alpha$ [55]. On the other side, in randomized-controlled trials carried out on sedentary [56], obese and T2D subjects $[19,22,57,58]$, the practice of regular exercise is associated with a decrease of IL-6. Interestingly, the decrease in IL-6 seems to pair with an augmented expression of cytokine within the muscle [58]. On this point, some evidence shows that muscle-derived IL- 6 suppresses adipose tissue macrophages accumulation, diminishing adipose tissue inflammation $[42,59]$ and stimulating glucose uptake and fatty acids oxidation in myocytes 
[51,52]. In contrast, adipocyte-secreted IL-6, leads to macrophage infiltration and M1 shifting in adipose tissue [42]. These suggestions lead to hypothesize that exercise stimulates an overall reduction of immune cells/adipocyte-derived IL-6, while preserving muscle IL- 6 secretion. Further, IL- 6 is typically upregulated only for a short time-frame after a session of exercise; on the contrary, regular exercise reduces basal IL- 6 production as well as the acute IL-6 plasma response upon exercise [36]. Thereby, the improvement in adipose tissue functionality upon exercise together with the effect of continued physical activity may account for the lower basal IL-6 levels recorded in dysmetabolic subjects, undergoing training. Altogether, these insights indicate that IL-6 effects may depend upon: i) the physiological context and the presence of obesity or metabolic alterations ii) exercise intensity and training length iii) secretion pattern (chronic or acute) iv) the site of production; v) the parallel increase of other mediators [42]. On this last point, evidence shows that the blockage of TNF $\alpha$ transcription, pairs with a significant decrease in IL-6, suggesting that IL-6 grows parallelly or in response to TNF $\alpha$ [60]. In this sense, IL-6 function seems to be highly dependent by the network of circulating mediators and the overall systemic pathophysiological status $[42,61]$.

Another factor possibly accounting for IL-6 multimodal activity is the differing stimuli/pathways regulating its secretion in single cell types. In immune cells, for example, TNF $\alpha$ induces IL- 6 secretion following activation of the NF-к $\beta$ cascade [36]. Conversely, in the skeletal muscle, IL-6 secretion is stimulated by augmented cytosolic $\mathrm{Ca}^{+}$and the activation of $\mathrm{p} 38$ mitogen-activated protein kinase, calcineurin or lactic acid, during contraction [36]. Furthermore, in pro-inflammatory conditions such as autoimmune disease or severe obesity, plasma IL-6 elevation pairs with TNF $\alpha$ [60]. Indeed, the concurrent arise of IL-1 $\beta$ and TNF $\alpha$ seem to be pivotal for determining the beneficial/negative activity of IL-6 [36]. On the contrary, plasma TNF $\alpha$ level is downregulated following the exercise-induced increase of IL-6 [36].

Lastly, the different activation of signaling in target cells may contribute to explain the bimodal function of IL6. In the classical activation, IL-6 binds to IL-6 receptor- $\alpha /$ IL-6 family signal transducer (IL6-R $\alpha /$ IL6ST) complex at the plasma membrane [62]. Conversely, the trans activation is mediated by the interaction of IL-6ST with a soluble-IL6-R $\alpha$-IL-6 complex [62] and activates cells not expressing IL-6 receptor. Both signaling pathways induce downstream activation of the JAK1-STAT3 pathway $[48,62]$. However, while the classical pathway is responsible for the shifting toward the anti-inflammatory M2-machrophage phenotype [48] and suppression of macrophage accumulation and insulin resistance [48], the trans pathway, stimulates the macrophage infiltration in adipose tissue [63]. Han et al. found that a similar switch toward the activation of trans pathway occurs in animals lacking muscle IL-6 [42], suggesting that exercise-induced IL-6 probably activates the trans signaling in muscles.

\subsection{Exercise increases IL-10 and IL-15 levels}

IL-10 is classified as an anti-inflammatory cytokine [64]. IL-10 induces macrophage anti-inflammatory shifting via inhibiting of mTOR and optimizing mitochondrial status and oxidative metabolism. These changes are associated with a lower activation of NRLF and diminished IL-1 $\beta$ secretion [64]. IL-10 inhibits the production of TNF $\alpha$ by immune cells [65], elicits a suppressive effect on MHC-II [66], and mitigates its activation through inhibiting cathepsin S via activating STAT3 signalling [67]. Furthermore, IL-10 promotes the switch to M2-antiinflammatory macrophages, in injured muscle [68].

IL-10 expression is increased in trained muscles of exercised rodents [69] and its plasma levels typically increase after prolonged exercise [2,70]. In the study of Dagdeviren et al., mice overexpressing IL-10 showed less muscle inflammation and higher glucose uptake and were relatively protected from developing obesityinduced insulin resistance [71]. Conversely, the ablation of muscle-specific IL-10 receptor induced insulin resistance [71]. Of note, the secretion of IL-10 partly accounts for the acute anti-inflammatory of IL-6, as above suggested [54]. Several studies on humans demonstrated that prolonged sessions of training are capable of inducing a significant elevation in IL-10 plasma levels in healthy subjects [70]. Similarly, in T2D-affected subjects, exercise was demonstrated to elicit a sustained IL-10 increment in systemic circulation [72]. 
IL-15 is a myocyte-derived factor secreted in response to exercise. Although its role is still a matter of study $[73,74]$, IL-15 seems to be determinant in the regulation of inflammation [75], muscle-adipose tissue crosstalk and adipose tissue functionality $[9,73,76]$. IL-15 also ameliorates muscle insulin sensitivity, through activating JAK/STAT3 pathway [76]. IL-15 may improve muscle glucose homeostasis and oxidative metabolism in an autocrine/paracrine fashion [76]. Indeed, IL-15 administration was shown to improve insulin sensitivity in mice [77]. IL-15 is typically lower in obesity [78] and muscle derived IL-15 seems to be negatively associated with adipose tissue mass in humans [79]. IL-15 is thought to mediate the suppression of muscle TNF $\alpha$ and its negative metabolic effects in patients affected by chronic conditions with high inflammatory status [80] or T2D [81].

In mice undergoing an acute bout of endurance exercise, muscle and plasma expression of IL-15 increased significantly [82]. This effect is probably due to an muscle AMP-activated protein kinase (AMPK) activation, upon exercise [82]. IL-15 was also shown to augment muscle lipid oxidation and gene expression of PPAR $\delta$ and PGC- $1 \alpha / \beta$, in trained mice $[82,83]$. In healthy humans, a significant increase of IL-15 was reported in interventional studies $[84,85]$. However, the dynamics of circulating IL-15 during exercise has been not exhaustively characterized $[73,85]$. In a randomized-controlled trial, in obese-dysmetabolic subjects, continuous training was shown to reduce circulating IL-15 [58]. As for IL-6, probably the pathophysiological context affects IL-15 dynamics; other variables such as adipose tissue dysfunction and training duration concur to determine IL-15 overall plasma levels. Of note, IL-15 growth seems to typically occur after an acute session of exercise, whereas prolonged exercise does not affect its levels [85]. Furthermore, IL-15 activity is also regulated by the concentrations of its soluble receptor, which determinates the actual availability of its active fraction (free IL-15) [76]. This body of evidence suggests IL-15 as possible key-player in the regulation of metabolic/inflammatory status. Nevertheless, IL-15 needs be further characterized to clearly understand its physiological role in dysmetabolic-exercised subjects.

\subsection{Exercise downregulates key pro-inflammatory mediators}

TNF $\alpha$ is increased in chronic inflammatory diseases [86] and represents a key-player in the development of peripheral insulin resistance and gluco-metabolic imbalance [60,87-89]. TNF $\alpha$ is responsible for the activation of NF-K $\beta$ and c-jun N-terminal kinase (JNK), which inhibit IRS1/2 [90]. TNF $\alpha$ also induces insulin resistance in pancreatic $\beta$-cells [91] and interferes with lipidemic balance [92] by altering hepatic gluco-lipidic and decreasing lipoprotein-lipase activity [92].

Mechanistic studies in humans indicate that acute elevations of IL-6, IL-10, and IL-15, induced by exercise, exert part of their anti-inflammatory effects by inhibiting circulating TNF $\alpha[55,65,81]$. Exercise is thought to enhance insulin sensitivity via the inhibition of TNF $\alpha$ [45]. High intensity exercise resulted effective in the mitigation of TNFa release upon endotoxin stimulation from human monocytes, ex vivo [93]. Regular physical activity decreases TNF $\alpha$ mRNA and protein expression in the skeletal muscle of rats [69]. An acute bout of exercise in HFD-fed obese rats induced a significative reduction of TNF $\alpha$ levels [94]. Similarly, a single session of exercise was capable to suppress the endotoxin-induced augment of circulating TNF $\alpha$ in mice [95] and humans [55]. In randomized-controlled trials in healthy [96] and dysmetabolic subjects [97], training was shown to be effective in lowering circulating levels of TNF $\alpha$, likely by stimulating the production of its soluble receptor [97].

IL-16 plays a pivotal role in determining adipose tissue inflammation, glucose balance, and the development of T2D [7,8]. IL-1 $\beta$ suppresses IRS-1 and AKT and UCP-1 expression, in adipose tissue [98-100]. The knocked-out for IL-1 $\beta$ receptor prevents the development of glycemic perturbations [101]. Conversely, the inhibition of IL$1 \beta$ is able to restore glucose homeostasis in T2D subjects [8]. 
Exercise induces a significant increase in IL-1ra [49,102]. IL-1ra can inhibit IL-1 $\beta$ signal transduction [103] and it was demonstrated to downregulate the glycolytic cascade in pro-inflammatory $T$ helper 17 , thus limiting their activity [104]. Thereby, the increase in IL-1ra, may contribute to protect against IL-1 $\beta$ negative effects on insulin sensitivity [54]. Experimental investigations on rodents seem to confirm a suppressive effect of exercise on IL-1 $\beta[94,105]$. Intense treadmill running over 7 weeks reduced concentrations of IL-1 $\beta$ in adipose tissue [105]. Similarly, an acute session of swimming was found to reduce IL-1 $\beta$ serum levels in HFD-fed, obese rats [94].

In morbid obesity and T2D, the lack of insulin signal $[18,106]$ enhances chronic FFAs release from adipose tissue [106]. FFAs activate macrophages [27] and trigger the expression of IL-6, MCP-1 and TNF in adipose tissue $[26,27]$ and in myocytes $[28,107]$. Adipose tissue-released FFAs propel liver insulin resistance and inflammation via activating TRLs-NF-KB and JNK signalling $[44,106,108]$. Conversely, FFAs reduction improves insulin sensitivity [109]. Further, the coexistence of elevated levels of FFAs and hyperglycemia promotes pancreatic $\beta$-cells failure [110].

Exercise reduces adipose tissue mass, improves its function and intrinsic inflammatory status (see section 5) [111]. This is likely to improve insulin sensitivity and may help mitigating lipolysis and the chronic release of FFAs into circulation in obese-dysmetabolic subjects [112].

Different studies demonstrate that regular exercise lowers plasmatic FFAs in subjects with obesity and hepatic steatosis [113] or cardiovascular disturbances [114], indicating that trunk adipose tissue accumulation, is associated with FFAs plasma levels [114]. The augmented clearance of FFAs from the bloodstream [115], secondary to regular exercise, potentially contributes to blunt muscle and liver functional impairment in obese-T2D subjects, hence ameliorating gluco-metabolic homeostasis. Indeed, training was demonstrated to help control circulating FFAs independently of body weight changes [116]. In an elegant randomized-controlled trial, Salomon et colleagues demonstrated that FFAs and peripheral insulin resistance diminished significantly in obese subjects undergoing a 3-month training. Intriguingly, the exercise-induced improvements on both markers occurred independently of weight loss and FFA turnover, thus probably being dependent upon increased muscle FFA oxidation [116].

MCP-1 is a monocyte chemotactic factor likely representing the negative pathway in the adipose tissuemuscle interplay [117]. MCP-1 is typically higher in obese-dysmetabolic subjects and correlates with the degree of visceral adiposity $[18,117,118]$. Adipose tissue-derived MCP-1 reduces glucose tolerance and insulin sensitivity and is implicated in the development of liver steatosis [118]. Circulating MCP-1 impairs myocytes insulin signalling [117] and reduces insulin-stimulated glucose uptake in myocytes through ERK1/2 activation. Some evidence indicates that MCP-1 expression in skeletal muscle grows after a bout of exercise [31,119], probably as an adaptive response to muscle stress after exercise [120]. In a recent intervention on healthy subjects, a slight increase in MCP-1 was recorded after 2 weeks of moderate training [56]. The study showed a positive correlation between the increase in abdominal glucose uptake and MCP-1 levels, suggesting a possible role of muscle-derived MCP-1 in the enhancement of adipose tissue insulin sensitivity. Although intriguing, muscle MCP-1 secretion and its systemic effects are still poorly characterized [26,31,121]. Experimental models demonstrate a decrease in MCP-1 circulating levels, following exercise, in both health and dysmetabolic conditions [58,94,96,122]. An acute session of exercise in obese HFD-fed rats induced a decrease in MCP-1 [94]. In randomized-controlled trials, prolonged training was demonstrated to decrease in MCP-1 plasma levels in healthy [96], obese-insulin resistant $[58,123]$ and metabolic syndrome-affected subjects [124]. In this last intervention, MCP-1 reduction was statistically correlated with adipose tissue mass decrease. This is in line with findings demonstrating that the reshaping of adipose tissue function, following exercise, lowers MCP-1 [22,96,122]. In this sense, exercise modulation of adipose tissue may be critical for regulating plasma MCP-1 levels in dysmetabolic subjects. 
Table 1. Table showing the potential effects of exercise on principal mediators involved in the regulation of metabolic homeostasis.

\begin{tabular}{|c|c|c|c|}
\hline Mediator & $\begin{array}{c}\text { Pro/anti-inflammatory } \\
\text { Effect* }\end{array}$ & $\begin{array}{l}\text { Metabolic effect } \\
\text { elicited* }^{*}\end{array}$ & $\begin{array}{l}\text { Effect of } \\
\text { Exercise }\end{array}$ \\
\hline$A T-I L-6$ & $\begin{array}{l}\text { Leucocyte infiltration in WAT } \\
\text { Liver inflammation }\end{array}$ & $\begin{array}{l}\text { Liver, SM and WAT insulin resistance. } \\
\text { Stimulation of WAT release of FFAs }\end{array}$ & Chronic training \\
\hline SM-IL-6 & $\begin{array}{l}\text { Immune cell tolerance } \\
\text { Inhibits WAT macrophage accumulation } \\
\text { Suppression of TNFa }\end{array}$ & $\begin{array}{l}\text { Lypolisis and lipid oxidation in SM } \\
\text { WAT Increased glucose uptake in SM } \\
\text { Browning of WAT }\end{array}$ & $\hat{T}$ Acute exercise \\
\hline IL-10 & $\begin{array}{l}\text { TNF } \alpha \text { and MHC-II suppression } \\
\text { Machropage anti-inflammatory setting } \\
\text { Inhibition of IL-B release }\end{array}$ & $\begin{array}{l}\text { Control of peripheal insulin sensitivity } \\
\text { Inhibition of liver steatosis }\end{array}$ & $\boldsymbol{\varphi}$ \\
\hline SM-IL-15 & Not defined/immunoregulatory? & $\begin{array}{l}\text { WAT loss, lipolysis } \\
\text { Increases SM oxidative capacity } \\
\text { Increases Insulin sensitivity } \\
\text { Decreases WAT dysfunction }\end{array}$ & $\begin{array}{l}\uparrow \text { Acute exercise } \\
\downarrow \text { Chronic training }\end{array}$ \\
\hline IL1-ra & $\begin{array}{l}\text { Antagonization of IL-B activity? } \\
\text { Limits T helper-17 activity }\end{array}$ & $\begin{array}{l}\text { Increased insulin sensitivity? } \\
\beta \text {-cells protection }\end{array}$ & $\uparrow$ \\
\hline TNF $\alpha$ & $\begin{array}{l}\text { M1 shifting } \\
\text { Immune cell infiltration } \\
\text { Immune cell activation }\end{array}$ & $\begin{array}{l}\text { Peripehal Insulin resistance } \\
\beta \text {-cells insulin resistance } \\
\text { BAT whitening } \\
\text { Liver steatosis }\end{array}$ & $\downarrow$ \\
\hline IL-1B & $\begin{array}{l}\text { Increase of NF-KB expression in } \\
\text { adipocytes and immune cells }\end{array}$ & $\begin{array}{l}\text { Peripheal insulin resistance } \\
\beta \text {-cells inflammation } \\
\text { BAT whitening }\end{array}$ & $\downarrow$ \\
\hline FFAs & $\begin{array}{l}\text { Macrophage activation } \\
\text { M1 shifting } \\
\text { Liver and SM inflammation }\end{array}$ & $\begin{array}{l}\text { WAT, SM and liver insulin resistance } \\
\text { Liver steatosis } \\
\beta \text {-cells inflammation }\end{array}$ & $\downarrow$ \\
\hline${ }^{\S} \mathrm{MCP}-1$ & Macrophage infiltration & $\begin{array}{l}\text { WAT and liver insulin resitance } \\
\text { Peripheal insulin resistance }\end{array}$ & $\downarrow$ Chronic training \\
\hline
\end{tabular}

WAT: white adipose tissue. BAT: brown adipose tissue. M1: macrophages type 1. M2 macrophages type 2. AT: adipose tissue-derived IL-6. SM: skeletal muscle. SM-secreted IL-6. SM-IL-15: SM-secreted IL-15

* The metabolic/inflammatory effects of mediators reported remain not completely defined.

$\S$ The effects are referred to non-muscle MCP-1.

\section{Exercise ameliorates low-grade inflammation by mitigating adipose tissue dysfunction}

Both untrained muscles [29] and excessive abdominal adiposity are associated with systemic inflammation, hyperglycemia, and insulin resistance $[9,18]$. The reduction of adipose tissue mass, secondary to regular 
exercise, associates with lower levels of MCP-1, IL-6, FFAs and TNF $\alpha$ in obese-dysmetabolic subjects $[112,114,116,123]$. This suggests that, part of the regulatory activity of exercise on low-grade inflammation results from the re-tuning of adipose tissue mass and functionality [22] (figure 1). Regular exercise directly decreases adipose tissue mass through augmenting energy expenditure and stimulating glucose and triglycerides (TGC) disposal from blood stream [9,112]. As mentioned, cytokines produced by trained muscles probably mediate, to some extent, the reduction of adipose tissue mass [45,52,53]. Muscle-derived IL-6 stimulates lipolysis $[45,51,53]$ and FFAs oxidation via activating AMPK in adipocytes [51]. Conversely, the inhibition of IL-6 outweighs the effect of exercise on adipose tissue loss [45,51]. Experiments in mice models show that exercise-derived IL-6 prevents obesity and stems hepatic TGC storage [53]. In mice, the complete absence of IL- 6 leads to develop obesity over the course of growth; this condition is partially reversed by the administration of exogenous IL-6 [125], denoting a direct regulatory effect of muscle IL-6 on adipocytes (figures 1,2). In this light, it is plausible that the regulatory effect on adipose function may account for the chronic reduction of IL-6 levels observed in trained dysmetabolic subjects $[19,22,58]$, as previously elucidated. Brain-derived neurotropic factor (BDNF) is another muscle-secreted active metabolite hypothesized to enhance fat oxidation in adipose tissue [126], thus contributing to regulate adipose tissue expansion.

Regular exercise improves white adipocyte functionality and inflammatory state $[111,127]$. It was shown to reduce macrophage accumulation [22] and promote the shifting toward M2 phenotype [128]. Exercise also suppresses the production of in-loco TNF $\alpha$ [129] and IL-1 [105], thus fostering adipose tissue shifting toward a non-inflammatory phenotype [111]. In a recent randomized-controlled trial, the concentration of CD36+ macrophages and TRL2, IL-8 and TNF $\alpha$ in adipose tissue of exercised-obese women were significantly diminished following continued exercise [111]. The optimization of energy balance and TGC storage in adipocytes probably underlies the anti-inflammatory effect of exercise on adipose tissue [58]; the improved oxidation of energy substrates mitigates adipocytes hypertrophy and the cascade of events leading to adipose tissue dysfunction [18]. However, as above illustrated, muscle-derived mediators (e.g., IL-6, IL-15, BDNF) seem to have a role in this respect. A recently-discovered exercise-induced metabolite -meteorin-like protein(METRNL) is likely to improve inflammatory conditions and insulin sensitivity in adipose tissue in obesity and dysmetabolic conditions [130].

Exercise can also influence adipose tissue metabolic/inflammatory homeostasis via enhancing the browning of white adipocytes [24,131]. The white-shifting of brown adipocytes increases adipose tissue inflammation [131]. Conversely, brown and mitochondrial-rich white adipocytes (brown-like or beige) improve glucose and FFAs clearance from bloodstream [24,132] and elicit an anti-inflammatory and immunoregulatory activity $[133,134]$. The regular practice of physical activity, upregulates metabolites such as METRNL [135] and irisin [136], which induce the brown-shifting of white adipocytes [127], thus ameliorating adipose tissue homeostasis [18,24,131]. Embryonic evidence from mice studies suggests that also exercise-induced IL-6 is possibly implicated in the browning of white adipocytes $[53,137]$. In addition, exercise-induced mediators such as hepatic FGF21 [138] seem to contribute to this process, in humans. 
A.

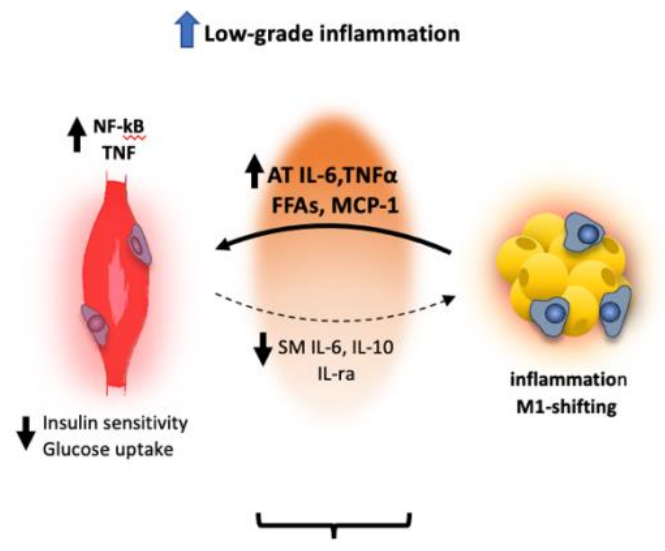

METABOLIC UNBALANCE
B.

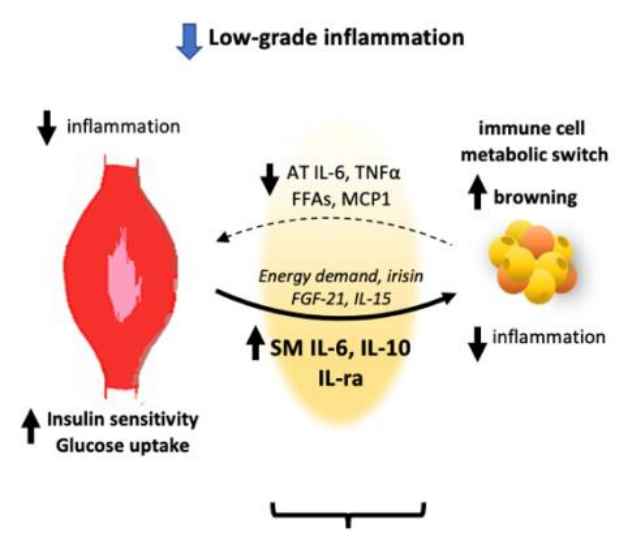

METABOLIC HEALTH

Figure 1. Effects of inactivity (A) and Exercise (B) on the modulation of muscle-adipose tissue crosstalk and low-grade systemic inflammation.

AT IL-6: Adipose tissue-derived IL-6. SM IL-6: Skeletal muscle-derived IL-6.

\section{Regular exercise lowers plasma LPS concentration by improving gut-microbiota health}

Growing evidence underpins the association of systemic inflammation [139], obesity and dysmetabolic conditions [140] with dysbiosis, higher gut-epithelium permeability and local infiltration of immune cells. In rodents, the suppression of immune-mediated inflammation in the gut, decreases adipose tissue inflammation and insulin resistance [141]. As for systemic inflammation, it is unclear whether inflammation represents a cause or rather a consequence of dysmetabolic conditions and obesity. The disruption of proper colonocytesmicrobiota interplay drives systemic inflammation [142] and adipose tissue dysfunction [143,144]. Of note, incorrect nutrition habits and diets per se predispose to gut microbiota ecotype switch and augmented gut permeability [145]. On the other side, obesity seems to be associated with increased gut permeability independent of dietary changes, suggesting that the adipose tissue-induced systemic sub-inflammation might influence gut functionality [146] (figure 2). Therefore, obesity-driven inflammation may modulate intestinal epithelial and resident immune cells toward a pro-inflammatory phenotype [48]. This would increase gut permeability, allowing the translocation into circulation of pro-inflammatory molecules such as bacterial-LPS, [142] oxidized FFAs and antigens [143,144,146]. Such mediators sustain systemic inflammation [142] by activating innate immunity [147], inducing M1-machrophages polarization [148,149] and adipose tissue inflammation [150-153]. Chiefly LPS, via binding TRLs, is responsible for the stimulation of pro-inflammatory pathways in adipocytes, macrophages and different cell types [142]. Higher LPS plasma levels are demonstrated to be associated with systemic metabolic impairment $[142,150]$. Exercise exerts a rebalancing activity on gut inflammation and functionality $[139,154]$. Regular exercise prevents the risk of developing inflammatory bowel conditions [154] and physical activity was shown to be effective in reducing COX-2 expression in the duodenum and ileum of HFD-fed animals [155]. This regulatory activity of exercise is probably related to: i) the exercise-mitigating effect on low-grade inflammation and 
adipose tissue accumulation (which impair gut functionality) [155]; ii) the positive effects of exercise on gutmicrobiota milieu. On this last point, growing evidence suggests that exercise can remodulate the ratio between beneficial and pro-inflammatory phyla [139,156,157]. Exercise augmented microbiota diversity in HFD-fed dysmetabolic mice and ameliorated gut-barrier integrity $[140,155]$. Voluntary running improved microbiota composition and $\mathrm{N}$-butyrate concentration in the gut lumen of leans mice [156], boosting mucosal health. Interestingly, changes of microbiota upon exercise seem to occur regardless of type of diet consumed [155], which discloses an independent and effective action of exercise. In humans, the practice of constant exercise increased diversity and abundance of Faecalibacterium prausnitzii and Akkermansia muciniphila [157], which are thought to be relevant for the maintenance of a health intestinal ecosystem. Of note, the microbiota switch was paired by a decrease in adipose tissue mass [157], indicating that adipose tissue-related inflammation could be implicated in the negative modulation of microbiota, and vice versa. As mentioned, the restoration of gut permeability, in dysmetabolic subjects, lowers the translocation of bacterial antigens and LPS from the gut lumen [142]. An observational study of Lira et al. demonstrated that trained subjects show lower concentration of plasma LPS compared to sedentary individuals [158]. In HFD-fed mice, the practice of regular moderate-intensity training successfully decreased LPS levels [140]. Similarly, in intervention studies on dysmetabolic individuals, continuous moderate-intensity exercise was sufficient to mitigate LPS translocation in the bloodstream, lowering its plasma concentration $[97,159]$.

\section{Exercise can control the formation of advanced glycation end-products}

Circulating advanced glycation end-products (AGEs) function as potential stimulators of systemic inflammation [160] and likely contribute to the genesis of obesity [161]. AGEs are considered as both the cause as well as the consequence of insulin resistance and T2D and represent a common pathophysiological soil of such metabolic disorders [17]. AGEs endogenous formation is primarily propelled by hyperglycemia and augmented levels of oxidative stress [160]. AGEs-receptors are located on a variety of cell types including immune cells, adipocytes, and hepatocytes. AGEs binding their specific receptor RAGEs or to specific receptors such as CD36 and AGE receptor 1 [17]. The binding of AGEs elicits the activation of the nuclear Ras-mitogen-activated protein kinase and transcription factor NF-k $\beta$ and the production of pro-inflammatory and chemo-actants responsible for the recruitment of immune cells and the build-up of inflammation [17]. In skeletal muscle, AGEs activate pathways conductive to protein degradation and impairment of AMPK and AKT signaling [162].

Exercise, by activating muscle glucose uptake, contributes to glucose balance and to enhance glycemic control in humans [163], blunting the formation of AGEs. The higher energy requirement, in trained organisms, diminishes the availability of glycating intermediates deriving from glycolytic (glucose-6-phosphate; fructose-6phosphate) and polyol (fructose-3-phosphate; 3- deoxyglucosone) pathways [13,164,165]. Higher levels of Inflammation and the activation of immune cells represent a potential trigger for the increase in oxidative stress. In this sense, the control of systemic inflammation exerted by exercise, could contribute to lowering circulating AGEs [166] (figure 2). In interventional models, training was indeed shown to efficiently decrease AGEs in obese-diabetic rodents $[164,167]$. Similarly, in humans, the practice of regular exercise was demonstrated to be effective in lowering AGEs levels in chronic inflammation [166] and soluble RAGEs in obese-dysglycemic patients [165] . 


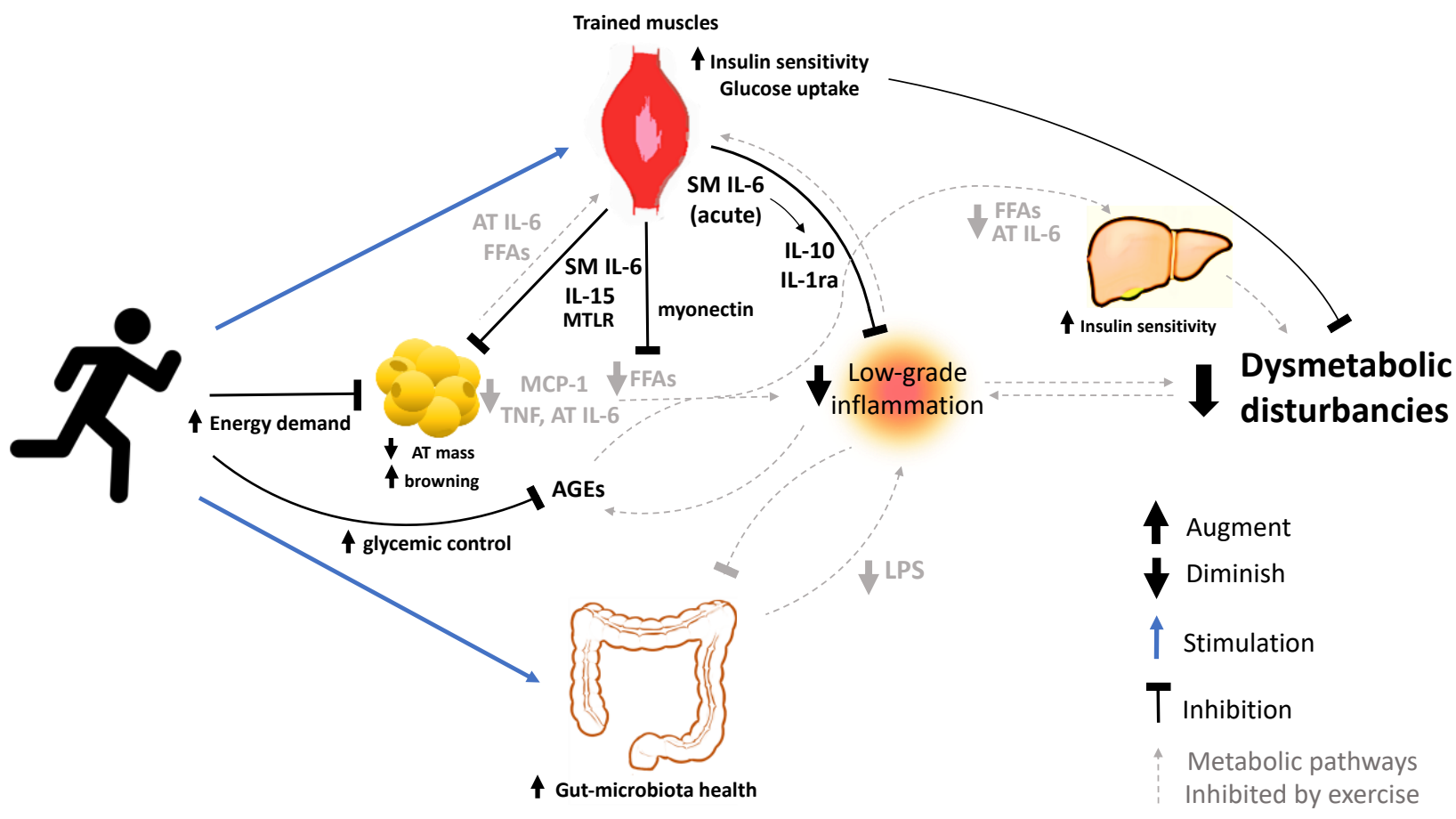

Figure 2. Synoptical scheme showing the potential role of exercise in the modulation on the main pathways regulating systemic inflammation and gluco-metabolic balance.

AT IL-6: Adipose tissue-derived IL-6. SM IL-6: Skeletal muscle-derived IL-6.

\section{Conclusion}

Circulating mediators form an articulated network of signaling, which is instrumental for whole-body metabolic regulation. Sedentariness, nutritional excess, and poor lifestyle habits promote the functional impairment at key-metabolic sites such as muscle, adipose tissue, and the gut. The cytokine interplay between dysfunctional organs reverberates systemically inducing alterations in cardio-metabolic homeostasis. Exercise is capable of directly or indirectly acting upon the equilibrium of key pro-inflammatory metabolites involved in the development of low-grade inflammation, thus warranting systemic metabolic health. We outlined plausible lines of explanation for the positive effects elicited by exercise, in dysmetabolic conditions. However, these mediators show a high complexity. Different regulating molecules need to be further characterized in their physiology. In addition, factors such as exercise intensity, time-duration, and the pathophysiological background influence the extent by which exercise can be favorable against low-grade inflammation. The knowledge on this topic is constantly enriched by novel data from cutting edge research, both on humans and animals. Future investigations may be resolving some pathophysiological uncertainties in the discussed model (figure $1 \mathrm{~A}$ ). 


\section{Conflict of interest}

The authors declare no conflict of interest

\section{Financial support}

This research did not receive any specific grant from funding agencies in the public, commercial, or not-forprofit sectors.

\section{Contribution statement}

Lucio Della Guardia: Conceptualization, Investigation and Writing.

Roberto Codella: Conceptualization, Supervision and Editing.

\section{References}

[1] S. Sitia, F. Atzeni, P. Sarzi-Puttini, V. Di Bello, L. Tomasoni, L. Delfino, F. Antonini-Canterin, G. Di Salvo, V. De Gennaro Colonna, S. La Carrubba, S. Carerj, M. Turiel, Cardiovascular involvement in systemic autoimmune diseases, Autoimmun. Rev. 8 (2009) 281-6.

https://doi.org/10.1016/j.autrev.2008.08.004.

[2] K. Karstoft, B.K. Pedersen, Exercise and type 2 diabetes: Focus on metabolism and inflammation, Immunol. Cell Biol. (2016). https://doi.org/10.1038/icb.2015.101.

[3] J. Lasselin, L. Capuron, Chronic low-grade inflammation in metabolic disorders: Relevance for behavioral symptoms, Neuroimmunomodulation. 21 (2014) 95-101. https://doi.org/10.1159/000356535.

[4] C. Liu, X. Feng, Q. Li, Y. Wang, Q. Li, M. Hua, Adiponectin, TNF- $\alpha$ and inflammatory cytokines and risk of type 2 diabetes: A systematic review and meta-analysis, Cytokine. 86 (2016) 100-109. https://doi.org/10.1016/j.cyto.2016.06.028.

[5] A.D. Pradhan, J.E. Manson, J.E. Buring, P.M. Ridker, C-Reactive Protein, Interleukin 6, and Risk of Developing Type 2 Diabetes Mellitus, J. Am. Med. Assoc. 286 (2015).

[6] A. Fleischman, S.E. Shoelson, R. Bernier, A.B. Goldfine, Salsalate improves glycemia and inflammatory parameters in obese young adults, Diabetes Care. 31 (2008) 289-294. https://doi.org/10.2337/dc071338.

[7] C. Cavelti-Weder, A. Babians-Brunner, C. Keller, M.A. Stahel, M. Kurz-Levin, H. Zayed, A.M. Solinger, T. Mandrup-Poulsen, C.A. Dinarello, M.Y. Donath, Effects of gevokizumab on glycemia and inflammatory markers in type 2 diabetes, Diabetes Care. 35 (2012) 1654-1662. https://doi.org/10.2337/dc11-2219.

[8] C.M. Larsen, M. Faulenbach, A. Vaag, A. Vølund, J.A. Ehses, B. Seifert, T. Mandrup-Poulsen, M.Y. Donath, Interleukin-1-Receptor Antagonist in Type 2 Diabetes Mellitus, N. Engl. J. Med. 356 (2007) 1517-1526. https://doi.org/10.1056/nejmoa065213.

[9] N.J. Pillon, P.J. Bilan, L.N. Fink, A. Klip, Cross-talk between skeletal muscle and immune cells: Musclederived mediators and metabolic implications, Am. J. Physiol. - Endocrinol. Metab. 304 (2013) 453-65. https://doi.org/10.1152/ajpendo.00553.2012.

[10] L. Della Guardia, C. Roggi, H. Cena, Diet-induced acidosis and alkali supplementation, Int. J. Food Sci. Nutr. 67 (2016) 754-761. https://doi.org/10.1080/09637486.2016.1198889.

[11] L. Della Guardia, M.A. Thomas, H. Cena, Insulin sensitivity and glucose homeostasis can be influenced by metabolic acid load, Nutrients. 10 (2018). https://doi.org/10.3390/nu10050618.

[12] R. Codella, G. Lanzoni, A. Zoso, A. Caumo, A. Montesano, I.M. Terruzzi, C. Ricordi, L. Luzi, L. Inverardi, Moderate intensity training impact on the inflammatory status and glycemic profiles in NOD mice, J. Diabetes Res. 2015 (2015) 737586. https://doi.org/10.1155/2015/737586.

[13] R. Codella, L. Della Guardia, I. Terruzzi, A. Solini, F. Folli, E.M. Varoni, A. Carrassi, L. Luzi, Physical activity as a proxy to ameliorate inflammation in patients with type 2 diabetes and periodontal disease at high cardiovascular risk, Nutr. Metab. Cardiovasc. Dis. S0939-4753 (2021) 00215-5. https://doi.org/10.1016/j.numecd.2021.04.022.

[14] R. Codella, L. Luzi, L. Inverardi, C. Ricordi, The anti-inflammatory effects of exercise in the syndromic thread of diabetes and autoimmunity, Eur. Rev. Med. Pharmacol. Sci. (2015). 
[15] R. Codella, A. Chirico, F. Lucidi, A. Ferrulli, A. La Torre, L. Luzi, The immune-modulatory effects of exercise should be favorably harnessed against COVID-19, J. Endocrinol. Invest. (2020).

https://doi.org/10.1007/s40618-020-01403-5.

[16] V. Rakotoarivelo, B. Variya, S. Ilangumaran, M.F. Langlois, S. Ramanathan, Inflammation in human adipose tissues-Shades of gray, rather than white and brown, Cytokine Growth Factor Rev. 44 (2018) 28-37. https://doi.org/10.1016/j.cytogfr.2018.10.001.

[17] H. Vlassara, J. Uribarri, Advanced glycation end products (AGE) and diabetes: Cause, effect, or both?, Curr. Diab. Rep. (2014). https://doi.org/10.1007/s11892-013-0453-1.

[18] G. Maurizi, L. Della Guardia, A. Maurizi, A. Poloni, Adipocytes properties and crosstalk with immune system in obesity-related inflammation, J. Cell. Physiol. (2018). https://doi.org/10.1002/jcp.25855.

[19] Z. Yu, X. Ye, J. Wang, Q. Qi, O.H. Franco, K.L. Rennie, A. Pan, H. Li, Y. Liu, F.B. Hu, X. Lin, Associations of physical activity with inflammatory factors, adipocytokines, and metabolic syndrome in middle-aged and older chinese people, Circulation. (2009). https://doi.org/10.1161/CIRCULATIONAHA.108.833574.

[20] V. Frodermann, D. Rohde, G. Courties, N. Severe, M.J. Schloss, H. Amatullah, C.S. McAlpine, S. Cremer, F.F. Hoyer, F. Ji, I.D. van Koeverden, F. Herisson, L. Honold, G.S. Masson, S. Zhang, J. Grune, Y. Iwamoto, S.P. Schmidt, G.R. Wojtkiewicz, I.H. Lee, K. Gustafsson, G. Pasterkamp, S.C.A. de Jager, R.I. Sadreyev, J. MacFadyen, P. Libby, P. Ridker, D.T. Scadden, K. Naxerova, K.L. Jeffrey, F.K. Swirski, M. Nahrendorf, Exercise reduces inflammatory cell production and cardiovascular inflammation via instruction of hematopoietic progenitor cells, Nat. Med. (2019). https://doi.org/10.1038/s41591-0190633-x.

[21] D.L. Belavý, M. Möhlig, A. Pfeiffer, D. Felsenberg, G. Armbrecht, Preferential deposition of visceral adipose tissue occurs due to physical inactivity, Int. J. Obes. 38 (2014) 1478-1480. https://doi.org/10.1038/ijo.2014.26.

[22] J.M. Bruun, J.W. Helge, B. Richelsen, B. Stallknecht, Diet and exercise reduce low-grade inflammation and macrophage infiltration in adipose tissue but not in skeletal muscle in severely obese subjects, Am. J. Physiol. - Endocrinol. Metab. 290 (2006) E961-7. https://doi.org/10.1152/ajpendo.00506.2005.

[23] G. Maurizi, L. Babini, L. Della Guardia, Potential role of microRNAs in the regulation of adipocytes liposecretion and adipose tissue physiology, J. Cell. Physiol. 233 (2018) 9077-9086. https://doi.org/10.1002/jcp.26523.

[24] A. Giordano, A. Frontini, S. Cinti, Convertible visceral fat as a therapeutic target to curb obesity, Nat. Rev. Drug Discov. (2016). https://doi.org/10.1038/nrd.2016.31.

[25] K. Sun, J. Tordjman, K. Clément, P.E. Scherer, Fibrosis and adipose tissue dysfunction, Cell Metab. (2013). https://doi.org/10.1016/j.cmet.2013.06.016.

[26] D. Patsouris, J.J. Cao, G. Vial, A. Bravard, E. Lefai, A. Durand, C. Durand, M.A. Chauvin, F. Laugerette, C. Debard, M.C. Michalski, M. Laville, H. Vidal, J. Rieusset, Insulin resistance is associated with MCP1mediated macrophage accumulation in skeletal muscle in mice and humans, PLoS One. 9 (2014) e110653. https://doi.org/10.1371/journal.pone.0110653.

[27] V. Varma, A. Yao-Borengasser, N. Rasouli, G.T. Nolen, B. Phanavanh, T. Starks, C. Gurley, P. Simpson, R.E. McGehee, P.A. Kern, C.A. Peterson, Muscle inflammatory response and insulin resistance: Synergistic interaction between macrophages and fatty acids leads to impaired insulin action, Am. J. Physiol. - Endocrinol. Metab. 296 (2009) e1300-10. https://doi.org/10.1152/ajpendo.90885.2008.

[28] N.J. Pillon, K. Arane, P.J. Bilan, T.T. Chiu, A. Klip, Muscle cells challenged with saturated fatty acids mount an autonomous inflammatory response that activates macrophages, Cell Commun. Signal. 10 (2012) 30. https://doi.org/10.1186/1478-811X-10-30.

[29] M. Mutin-Carnino, A. Carnino, S. Roffino, A. Chopard, Effect of muscle unloading, reloading and exercise on inflammation during a head-down bed rest, Int. J. Sports Med. 35 (2014) 28-34. https://doi.org/10.1055/s-0033-1343407.

[30] O.S. Kwon, R.E. Tanner, K.M. Barrows, M. Runtsch, J.D. Symons, T. Jalili, B.T. Bikman, D.A. McClain, R.M. O'Connell, M.J. Drummond, MyD88 regulates physical inactivity-induced skeletal muscle inflammation, ceramide biosynthesis signaling, and glucose intolerance, Am. J. Physiol. - Endocrinol. Metab. 309 (2015) E11-E21. https://doi.org/10.1152/ajpendo.00124.2015.

[31] P. Tantiwong, K. Shanmugasundaram, A. Monroy, S. Ghosh, M. Li, R.A. DeFronzo, E. Cersosimo, A. Sriwijitkamol, S. Mohan, N. Musi, NF-KB activity in muscle from obese and type 2 diabetic subjects under basal and exercise-stimulated conditions, Am. J. Physiol. - Endocrinol. Metab. 299 (2010) E794801. https://doi.org/10.1152/ajpendo.00776.2009.

[32] F. L.N., O. A., J. T.E., S. A., B. M., K. A., Muscle-infiltrating macrophages in type 2 diabetes, Diabetes. 61 
(2012) A29.

http://www.embase.com/search/results?subaction=viewrecord\&from=export\&id=L70796732\%0Ahttp ://diabetes.diabetesjournals.org/content/61/Supplement_1/A1.full.pdf+html\%0Ahttp://dx.doi.org/10. 2337/db12-1-377.

[33] M. Saghizadeh, J.M. Ong, W.T. Garvey, R.R. Henry, P.A. Kern, The expression of TNFa by human muscle: Relationship to insulin resistance, J. Clin. Invest. 97 (1996) 1111-1116. https://doi.org/10.1172/JCl118504.

[34] F. Li, Y. Li, Y. Duan, C.A.A. Hu, Y. Tang, Y. Yin, Myokines and adipokines: Involvement in the crosstalk between skeletal muscle and adipose tissue, Cytokine Growth Factor Rev. 33 (2017) 73-82. https://doi.org/10.1016/j.cytogfr.2016.10.003.

[35] J.H. Yoon, P. Song, J.H. Jang, D.K. Kim, S. Choi, J. Kim, J. Ghim, D. Kim, S. Park, H. Lee, D. Kwak, K. Yea, D. Hwang, P.G. Suh, S.H. Ryu, Proteomic analysis of tumor necrosis factor-alpha (TNF- $\alpha$ )-induced L6 myotube secretome reveals novel TNF- $\alpha$-dependent myokines in diabetic skeletal muscle, J. Proteome Res. 10 (2011) 5315-5325. https://doi.org/10.1021/pr200573b.

[36] B.K. Pedersen, Anti-inflammatory effects of exercise: role in diabetes and cardiovascular disease, Eur. J. Clin. Invest. 47 (2017) 600-611. https://doi.org/10.1111/eci.12781.

[37] N. Nishimoto, T. Kishimoto, Inhibition of IL-6 for the treatment of inflammatory diseases, Curr. Opin. Pharmacol. 4 (2004) 386-391. https://doi.org/10.1016/j.coph.2004.03.005.

[38] K. Ishihara, T. Hirano, IL-6 in autoimmune disease and chronic inflammatory proliferative disease, Cytokine Growth Factor Rev. 13 (2002) 357-368. https://doi.org/10.1016/S1359-6101(02)00027-8.

[39] S.B. Jorgensen, H.M. O’Neill, L. Sylow, J. Honeyman, K.A. Hewitt, R. Palanivel, M.D. Fullerton, L. Öberg, A. Balendran, S. Galic, C. Van Der Poel, I.A. Trounce, G.S. Lynch, J.D. Schertzer, G.R. Steinberg, Deletion of skeletal muscle SOCS3 prevents insulin resistance in obesity, Diabetes. 62 (2013) 56-64. https://doi.org/10.2337/db12-0443.

[40] G. Sabio, M. Das, A. Mora, Z. Zhang, J.Y. Jun, J.K. Hwi, T. Barrett, J.K. Kim, R.J. Davis, A stress signaling pathway in adipose tissue regulates hepatic insulin resistance, Science (80-. ). 322 (2008) 1539-43. https://doi.org/10.1126/science.1160794.

[41] M. Whitham, M. Pal, T. Petzold, M. Hjorth, C.L. Egan, J.S. Brunner, E. Estevez, P. Iliades, B. Zivanovic, S. Reibe, W.E. Hughes, M. Findeisen, J. Hidalgo, M.A. Febbraio, Adipocyte-specific deletion of IL-6 does not attenuate obesity-induced weight gain or glucose intolerance in mice, Am. J. Physiol. Endocrinol. Metab. 317 (2019) E597-E604. https://doi.org/10.1152/ajpendo.00206.2019.

[42] M.S. Han, A. White, R.J. Perry, J.P. Camporez, J. Hidalgo, G.I. Shulman, R.J. Davis, Regulation of adipose tissue inflammation by interleukin 6, Proc. Natl. Acad. Sci. U. S. A. (2020). https://doi.org/10.1073/pnas.1920004117.

[43] J.J. Senn, P.J. Klover, I.A. Nowak, R.A. Mooney, Interleukin-6 induces cellular insulin resistance in hepatocytes, Diabetes. 51 (2002) 3391-3399. https://doi.org/10.2337/diabetes.51.12.3391.

[44] S. Wueest, F. Item, F.C. Lucchini, T.D. Challa, W. Müller, M. Blüher, D. Konrad, Mesenteric fat lipolysis mediates obesity-associated hepatic steatosis and insulin resistance, Diabetes. 65 (2016) 140-148. https://doi.org/10.2337/db15-0941.

[45] A.S. Wedell-Neergaard, L. Lang Lehrskov, R.H. Christensen, G.E. Legaard, E. Dorph, M.K. Larsen, N. Launbo, S.R. Fagerlind, S.K. Seide, S. Nymand, M. Ball, N. Vinum, C.N. Dahl, M. Henneberg, M. RiedLarsen, J.D. Nybing, R. Christensen, J.B. Rosenmeier, K. Karstoft, B.K. Pedersen, H. Ellingsgaard, R. Krogh-Madsen, Exercise-Induced Changes in Visceral Adipose Tissue Mass Are Regulated by IL-6 Signaling: A Randomized Controlled Trial, Cell Metab. 29 (2019) 844-855.e3. https://doi.org/10.1016/j.cmet.2018.12.007.

[46] H. Ellingsgaard, I. Hauselmann, B. Schuler, A.M. Habib, L.L. Baggio, D.T. Meier, E. Eppler, K. Bouzakri, S. Wueest, Y.D. Muller, A.M.K. Hansen, M. Reinecke, D. Konrad, M. Gassmann, F. Reimann, P.A. Halban, J. Gromada, D.J. Drucker, F.M. Gribble, J.A. Ehses, M.Y. Donath, Interleukin-6 enhances insulin secretion by increasing glucagon-like peptide-1 secretion from L cells and alpha cells, Nat. Med. 17 (2011) 14811489. https://doi.org/10.1038/nm.2513.

[47] J. Braune, U. Weyer, C. Hobusch, J. Mauer, J.C. Brüning, I. Bechmann, M. Gericke, IL-6 Regulates M2 Polarization and Local Proliferation of Adipose Tissue Macrophages in Obesity, J. Immunol. 198 (2017) 2927-2934. https://doi.org/10.4049/jimmunol.1600476.

[48] J. Mauer, B. Chaurasia, J. Goldau, M.C. Vogt, J. Ruud, K.D. Nguyen, S. Theurich, A.C. Hausen, J. Schmitz, H.S. Brönneke, E. Estevez, T.L. Allen, A. Mesaros, L. Partridge, M.A. Febbraio, A. Chawla, F.T. Wunderlich, J.C. Brüning, Signaling by IL-6 promotes alternative activation of macrophages to limit 
endotoxemia and obesity-associated resistance to insulin, Nat. Immunol. 15 (2014) 423-430. https://doi.org/10.1038/ni.2865.

[49] E. da S. Alves, R.V.T. dos Santos, F.S. de Lira, A.A. Almeida, K. Edwards, M. Benvenutti, S. Tufik, M.T. De Mello, Effects of intensity-matched exercise at different intensities on inflammatory responses in ablebodied and spinal cord injured individuals, J. Spinal Cord Med. apr 16 (2020) 1-11. https://doi.org/10.1080/10790268.2020.1752976.

[50] K. Ostrowski, T. Rohde, M. Zacho, S. Asp, B.K. Pedersen, Evidence that interleukin-6 is produced in human skeletal muscle during prolonged running, J. Physiol. 508 (1998) 949-953. https://doi.org/10.1111/j.1469-7793.1998.949bp.x.

[51] A.L. Carey, G.R. Steinberg, S.L. Macaulay, W.G. Thomas, A.G. Holmes, G. Ramm, O. Prelovsek, C. Hohnen-Behrens, M.J. Watt, D.E. James, B.E. Kemp, B.K. Pedersen, M.A. Febbraio, Interleukin-6 increases insulin-stimulated glucose disposal in humans and glucose uptake and fatty acid oxidation in vitro via AMP-activated protein kinase, Diabetes. 55 (2006) 2688-2697. https://doi.org/10.2337/db051404.

[52] E. Wolsk, H. Mygind, T.S. Grøndahl, B.K. Pedersen, G. Van Hall, IL-6 selectively stimulates fat metabolism in human skeletal muscle, Am. J. Physiol. - Endocrinol. Metab. 299 (2010) E832-40. https://doi.org/10.1152/ajpendo.00328.2010.

[53] L. Li, C. Huang, H. Yin, X. Zhang, D. Wang, C. Ma, J. Li, Y. Zhao, X. Li, Interleukin-6 mediated exerciseinduced alleviation of adiposity and hepatic steatosis in mice, BMJ Open Diabetes Res. Care. 9 (2021) e001431. https://doi.org/10.1136/bmjdrc-2020-001431.

[54] A. Steensberg, C.P. Fischer, C. Keller, K. Møller, B.K. Pedersen, IL-6 enhances plasma IL-1ra, IL-10, and cortisol in humans, Am. J. Physiol. - Endocrinol. Metab. 285 (2003) E433-7.

https://doi.org/10.1152/ajpendo.00074.2003.

[55] R. Starkie, S.R. Ostrowski, S. Jauffred, M. Febbraio, B.K. Pedersen, Exercise and IL-6 infusion inhibit endotoxin-induced TNF- $\alpha$ production in humans, FASEB J. 17 (2003) 1-10.

https://doi.org/10.1096/fj.02-0670fje.

[56] R.J.W. Middelbeek, P. Motiani, N. Brandt, P. Nigro, J. Zheng, K.A. Virtanen, K.K. Kalliokoski, J.C. Hannukainen, L.J. Goodyear, Exercise intensity regulates cytokine and klotho responses in men, Nutr. Diabetes. 11 (2021) 5. https://doi.org/10.1038/s41387-020-00144-x.

[57] Y. Hayashino, J.L. Jackson, T. Hirata, N. Fukumori, F. Nakamura, S. Fukuhara, S. Tsujii, H. Ishii, Effects of exercise on C-reactive protein, inflammatory cytokine and adipokine in patients with type 2 diabetes: A meta-analysis of randomized controlled trials, Metabolism. 63 (2014) 431-440.

https://doi.org/10.1016/j.metabol.2013.08.018.

[58] T. Christiansen, S.K. Paulsen, J.M. Bruun, S.B. Pedersen, B. Richelsen, Exercise training versus dietinduced weight-loss on metabolic risk factors and inflammatory markers in obese subjects: A 12-week randomized intervention study, Am. J. Physiol. - Endocrinol. Metab. 298 (2010) E824-31.

https://doi.org/10.1152/ajpendo.00574.2009.

[59] C.P. Fischer, Interleukin-6 in acute exercise and training: What is the biological relevance?, Exerc. Immunol. Rev. 12 (2006) 6-33.

[60] P.B. Rosenvinge A, Krogh-Madsen R, Baslund B, Insulin resistance in patients with rheumatoid arthritis: effect of anti-TNFalpha therapy., Scand J Rheumatol. 36 (2007) 91-6. https://doi.org/doi: 10.1080/03009740601179605.

[61] M.K. Nøhr, N. Bobba, B. Richelsen, S. Lund, S.B. Pedersen, Inflammation downregulates UCP1 expression in brown adipocytes potentially via SIRT1 and DBC1 interaction, Int. J. Mol. Sci. (2017). https://doi.org/10.3390/ijms18051006.

[62] J. Scheller, A. Chalaris, D. Schmidt-Arras, S. Rose-John, The pro- and anti-inflammatory properties of the cytokine interleukin-6, Biochim. Biophys. Acta - Mol. Cell Res. 1813 (2011) 878-888. https://doi.org/10.1016/j.bbamcr.2011.01.034.

[63] M.J. Kraakman, H.L. Kammoun, T.L. Allen, V. Deswaerte, D.C. Henstridge, E. Estevez, V.B. Matthews, B. Neill, D.A. White, A.J. Murphy, L. Peijs, C. Yang, S. Risis, C.R. Bruce, X.J. Du, A. Bobik, R.S. Lee-Young, B.A. Kingwell, A. Vasanthakumar, W. Shi, A. Kallies, G.I. Lancaster, S. Rose-John, M.A. Febbraio, Blocking IL-6 trans-signaling prevents high-fat diet-induced adipose tissue macrophage recruitment but does not improve insulin resistance, Cell Metab. 21 (2015) 403-416.

https://doi.org/10.1016/j.cmet.2015.02.006.

[64] W.K.E. Ip, N. Hoshi, D.S. Shouval, S. Snapper, R. Medzhitov, Anti-inflammatory effect of IL-10 mediated by metabolic reprogramming of macrophages, Science (80-. ). 356 (2017) 513-519. 
https://doi.org/10.1126/science.aal3535.

[65] T. Smallie, G. Ricchetti, N.J. Horwood, M. Feldmann, A.R. Clark, L.M. Williams, IL-10 inhibits transcription elongation of the human TNF gene in primary macrophages, J. Exp. Med. 207 (2010) 2081-2088. https://doi.org/10.1084/jem.20100414.

[66] B. Koppelman, J.J. Neefjes, J.E. De Vries, R. De Waal Malefyt, Interleukin-10 down-regulates MHC class II $\alpha \beta$ peptide complexes at the plasma membrane of monocytes by affecting arrival and recycling, Immunity. 7 (1997) 861-871. https://doi.org/10.1016/S1074-7613(00)80404-5.

[67] L.L.Y. Chan, B.K.W. Cheung, J.C.B. Li, A.S.Y. Lau, A role for STAT3 and cathepsin S in IL-10 downregulation of IFN- -induced MHC class II molecule on primary human blood macrophages, J. Leukoc. Biol. 88 (2010) 303-311. https://doi.org/10.1189/jlb.1009659.

[68] B. Deng, M. Wehling-Henricks, S.A. Villalta, Y. Wang, J.G. Tidball, IL-10 Triggers Changes in Macrophage Phenotype That Promote Muscle Growth and Regeneration, J. Immunol. 189 (2012) 3669-3680. https://doi.org/10.4049/jimmunol.1103180.

[69] S.M. Batista ML Jr, Rosa JC, Lopes RD, Lira FS, Martins E Jr, Yamashita AS, Brum PC, Lancha AH Jr, Lopes AC, Exercise training changes IL-10/TNF-alpha ratio in the skeletal muscle of post-MI rats. Cytokine. 2010 Jan;49(1):102-8. doi: 10.1016/j.cyto.2009.10.007. Epub 2009 Nov 30. PMID: 19948415., Cytokine. 49 (2009) 102-8.

[70] C. Cabral-Santos, E.A. de Lima Junior, I.M. da C. Fernandes, R.Z. Pinto, J.C. Rosa-Neto, N.C. Bishop, F.S. Lira, Interleukin-10 responses from acute exercise in healthy subjects: A systematic review, J. Cell. Physiol. 234 (2019) 9956-9965. https://doi.org/10.1002/jcp.27920.

[71] S. Dagdeviren, D.Y. Jung, E. Lee, R.H. Friedline, H.L. Noh, J.H. Kim, P.R. Patel, N. Tsitsilianos, A. V. Tsitsilianos, D.A. Tran, G.H. Tsougranis, C.C. Kearns, C.P. Uong, J.Y. Kwon, W. Muller, K.W. Lee, J.K. Kim, Altered Interleukin-10 Signaling in Skeletal Muscle Regulates Obesity-Mediated Inflammation and Insulin Resistance, Mol. Cell. Biol. 36 (2016) 2956-2966. https://doi.org/10.1128/mcb.00181-16.

[72] N.P. Kadoglou, D. Perrea, F. Iliadis, N. Angelopoulou, C. Liapis, M. Alevizos, Exercise reduces resistin and inflammatory cytokines in patients with type 2 diabetes, Diabetes Care. (2007). https://doi.org/10.2337/dc06-1149.

[73] A. Pérez-López, J.A.L. Calbet, Discussion of "interleukin-15 as a myokine: Mechanistic insight into its effect on skeletal muscle metabolism" - interleukin-15 and interleukin-15r $\alpha$-dependent/-independent functions in human skeletal muscle are largely unknown, Appl. Physiol. Nutr. Metab. 44 (2019) 336337. https://doi.org/10.1139/apnm-2018-0769.

[74] I.B. McInnes, F.Y. Liew, Interleukin 15: A proinflammatory role in rheumatoid arthritis synovitis, Immunol. Today. 19 (1998) 75-79. https://doi.org/10.1016/S0167-5699(97)01205-X.

[75] M. Patidar, N. Yadav, S.K. Dalai, Interleukin 15: A key cytokine for immunotherapy, Cytokine Growth Factor Rev. 31 (2016) 49-59. https://doi.org/10.1016/j.cytogfr.2016.06.001.

[76] L. Nadeau, C. Aguer, Interleukin-15 as a myokine: Mechanistic insight into its effect on skeletal muscle metabolism, Appl. Physiol. Nutr. Metab. 44 (2019) 229-238. https://doi.org/10.1139/apnm-20180022.

[77] A.A. Barra NG, Chew MV, Holloway AC, Interleukin15 treatment improves glucose homeostasis and insulin sensitivity in obese mice. Diabetes Obes Metab 2012; 14: 190-193, Diabetes Obes Metab. 14 (2012) 190-193.

[78] N.G. Barra, S. Reid, R. MacKenzie, G. Werstuck, B.L. Trigatti, C. Richards, A.C. Holloway, A.A. Ashkar, Interleukin-15 contributes to the regulation of murine adipose tissue and human adipocytes, Obesity. 18 (2010) 1601-1607. https://doi.org/10.1038/oby.2009.445.

[79] A.R. Nielsen, P. Hojman, C. Erikstrup, C.P. Fischer, P. Plomgaard, R. Mounier, O.H. Mortensen, C. Broholm, S. Taudorf, R. Krogh-Madsen, B. Lindegaard, A.M.W. Petersen, J. Gehl, B.K. Pedersen, Association between interleukin-15 and obesity: Interleukin-15 as a potential regulator of fat mass, J. Clin. Endocrinol. Metab. 93 (2008) 4486-4493. https://doi.org/10.1210/jc.2007-2561.

[80] B. Pajak, S. Orzechowska, B. Pijet, M. Pijet, A. Pogorzelska, B. Gajkowska, A. Orzechowski, Crossroads of cytokine signaling - The chase to stop muscle cachexia, in: J. Physiol. Pharmacol., 2008: pp. 251-264.

[81] R. Sánchez-Jiménez, N. Alvarado-Vásquez, IL-15 that a regulator of TNF- $\alpha$ in patients with diabetes mellitus type 2, Med. Hypotheses. 80 (2013) 776-777. https://doi.org/10.1016/j.mehy.2013.03.009.

[82] J.D. Crane, L.G. Macneil, J.S. Lally, R.J. Ford, A.L. Bujak, I.K. Brar, B.E. Kemp, S. Raha, G.R. Steinberg, M.A. Tarnopolsky, Exercise-stimulated interleukin-15 is controlled by AMPK and regulates skin metabolism and aging, Aging Cell. 14 (2015) 625-634. https://doi.org/10.1111/acel.12341.

[83] T. (2013). Quinn, L. S., Anderson, B. G., Conner, J. D., and Wolden-Hanson, IL-15 overexpression 
promotes endurance, oxidative energy metabolism, and muscle PPARdelta, SIRT1, PGC-1alpha, and PGC-1beta expression in male mice. Endocrinology 154, 232-245. doi, Endocrinology. 154 (2013) 232245.

[84] Y. Tamura, K. Watanabe, T. Kantani, J. Hayashi, N. Ishida, M. Kaneki, Upregulation of circulating IL-15 by treadmill running in healthy individuals: Is IL-15 an endocrine mediator of the beneficial effects of endurance exercise?, Endocr. J. 58 (2011) 211-215. https://doi.org/10.1507/endocrj.K10E-400.

[85] S.E. Riechman, G. Balasekaran, S.M. Roth, R.E. Ferrell, Association of interleukin-15 protein and interleukin-15 receptor genetic variation with resistance exercise training responses, J. Appl. Physiol. 97 (2004) 2214-2219. https://doi.org/10.1152/japplphysiol.00491.2004.

[86] M. Farrugia, B. Baron, The role of TNF- $\alpha$ in rheumatoid arthritis: a focus on regulatory T cells, J. Clin. Transl. Res. 2 (2016) 84. - 90. https://doi.org/10.18053/jctres.02.201603.005.

[87] C.P. et al. Plomgaard, P., Nielsen, A.R., Fischer, Associations between insulin resistance and TNF- $\alpha$ in plasma, skeletal muscle and adipose tissue in humans with and without type 2 diabetes., Diabetologia. 50 (2007) 2562-2571.

[88] H.G. Uysal KT, Wiesbrock SM, Marino MW, Protection from obesity-induced insulin resistance in mice lacking TNF-alpha function., Nature. 9 (1997) 610-4.

[89] P.D. Miles, O.M. Romeo, K. Higo, A. Cohen, K. Rafaat, J.M. Olefsky, TNF-alpha-induced insulin resistance in vivo and its prevention by troglitazone, Diabetes. 46 (1997) 1678-1683. https://doi.org/10.2337/diabetes.46.11.1678.

[90] I. Nieto-Vazquez, S. Fernández-Veledo, D.K. Krämer, R. Vila-Bedmar, L. Garcia-Guerra, M. Lorenzo, Insulin resistance associated to obesity: The link TNF-alpha, Arch. Physiol. Biochem. 114 (2008) 183194. https://doi.org/10.1080/13813450802181047.

[91] M.M. Kwon G, Xu G, Marshall CA, Tumor necrosis factor alpha-induced pancreatic beta-cell insulin resistance is mediated by nitric oxide and prevented by 15-deoxy-Delta12,14-prostaglandin J2 and aminoguanidine. A role for peroxisome proliferator-activated receptor gamma activation and in, J Biol Chem. 274 (1999) 18702-8.

[92] W. Khovidhunkit, M.S. Kim, R.A. Memon, J.K. Shigenaga, A.H. Moser, K.R. Feingold, C. Grunfeld, Effects of infection and inflammation on lipid and lipoprotein metabolism: Mechanisms and consequences to the host, J. Lipid Res. 45 (2004) 1169-1196. https://doi.org/10.1194/jlr.R300019-JLR200.

[93] R.P. Sloan, P.A. Shapiro, R.E. DeMeersman, P.S. McKinley, K.J. Tracey, I. Slavov, Y. Fang, P.D. Flood, Aerobic exercise attenuates inducible TNF production in humans, J. Appl. Physiol. 103 (2007) 10071011. https://doi.org/10.1152/japplphysiol.00147.2007.

[94] F. Wasinski, R.F.P. Bacurau, M.R. Moraes, A.S. Haro, P.M.M. Moraes-Vieira, G.R. Estrela, E.J. ParedesGamero, C.C. Barros, S.S. Almeida, N.O.S. Câmara, R.C. Araujo, Exercise and caloric restriction alter the immune system of mice submitted to a high-fat diet, Mediators Inflamm. 2013 (2013) 395672. https://doi.org/10.1155/2013/395672.

[95] Y.H. Tanaka Y, Kawanishi N, Shiva D, Tsutsumi N, Uchida M, Kitamura H, Kato Y, Exhaustive exercise reduces tumor necrosis factor-alpha production in response to lipopolysaccharide in mice. Neuroimmunomodulation. 2010;17(4):279-86., Neuroimmunomodulation. 17 (2010) 279-86.

[96] J.K. Ihalainen, M. Schumann, D. Eklund, M. Hämäläinen, E. Moilanen, G. Paulsen, K. Häkkinen, A.A. Mero, Combined aerobic and resistance training decreases inflammation markers in healthy men, Scand. J. Med. Sci. Sport. 28 (2018) 40-47. https://doi.org/10.1111/sms.12906.

[97] K.K. Motiani, M.C. Collado, J.J. Eskelinen, K.A. Virtanen, E. Löyttyniemi, S. Salminen, P. Nuutila, K.K. Kalliokoski, J.C. Hannukainen, Exercise training modulates gut microbiota profile and improves endotoxemia, Med. Sci. Sports Exerc. 52 (2020) 94-104. https://doi.org/10.1249/MSS.0000000000002112.

[98] D.B. Ballak, R. Stienstra, C.J. Tack, C.A. Dinarello, J.A. van Diepen, IL-1 family members in the pathogenesis and treatment of metabolic disease: Focus on adipose tissue inflammation and insulin resistance, Cytokine. 75 (2015) 280-290. https://doi.org/10.1016/j.cyto.2015.05.005.

[99] T. Goto, S. Naknukool, R. Yoshitake, Y. Hanafusa, S. Tokiwa, Y. Li, T. Sakamoto, T. Nitta, M. Kim, N. Takahashi, R. Yu, H. Daiyasu, S. Seno, H. Matsuda, T. Kawada, Proinflammatory cytokine interleukin-1ß suppresses cold-induced thermogenesis in adipocytes, Cytokine. (2016). https://doi.org/10.1016/j.cyto.2015.11.001.

[100] D.C. García MDC, Pazos P, Lima L, Regulation of Energy Expenditure and Brown/Beige Thermogenic Activity by Interleukins: New Roles for Old Actors, Int J Mol Sci. 19 (2018) 2569. https://doi.org/10.3390/ijms19092569. 
[101] F.C. McGillicuddy, K.A. Harford, C.M. Reynolds, E. Oliver, M. Claessens, K.H.G. Mills, H.M. Roche, Lack of interleukin-1 receptor I (IL-1RI) protects mice from high-fat diet-induced adipose tissue inflammation coincident with improved glucose homeostasis, Diabetes. 60 (2011) 1688-1698. https://doi.org/10.2337/db10-1278.

[102] P.M. Haahr, B.K. Pedersen, A. Fomsgaard, N. Tvede, M. Diamant, K. Klarlund, J. Halkjaer-Kristensen, K. Bendtzen, Effect of physical exercise on in vitro production of interleukin 1, interleukin 6, tumour necrosis factor- $\alpha$, interleukin 2 and interferon- $\gamma$, Int. J. Sports Med. 12 (1991) 223-227. https://doi.org/10.1055/s-2007-1024672.

[103] C.A. Dinarello, The interleukin-1 family: 10 years of discovery 1, FASEB J. 8 (1994) 1314-1325. https://doi.org/10.1096/fasebj.8.15.8001745.

[104] C.M. Park MJ, Lee SH, Lee SH, Lee EJ, Kim EK, Choi JY, IL-1 Receptor Blockade Alleviates Graft-versusHost Disease through Downregulation of an Interleukin-13-Dependent Glycolytic Pathway in Th17 Cells., Mediat. Inflamm. 2015 (2015) 631384.

[105] D. Gomez-Merino, C. Drogou, C.Y. Guezennec, M. Chennaoui, Effects of chronic exercise on cytokine production in white adipose tissue and skeletal muscle of rats, Cytokine. 40 (2007) 23-29. https://doi.org/10.1016/j.cyto.2007.07.188.

[106] G. Boden, Obesity, insulin resistance and free fatty acids, Curr. Opin. Endocrinol. Diabetes Obes. 18 (2011) 139-143. https://doi.org/10.1097/MED.0b013e3283444b09.

[107] T. Coll, X. Palomer, F. Blanco-Vaca, J.C. Escolà-Gil, R.M. Sánchez, J.C. Laguna, M. Vázquez-Carrera, Cyclooxygenase 2 inhibition exacerbates palmitate-induced inflammation and insulin resistance in skeletal muscle cells, Endocrinology. 151 (2010) 537-548. https://doi.org/10.1210/en.2009-0874.

[108] G. Boden, P. She, M. Mozzoli, P. Cheung, K. Gumireddy, P. Reddy, X. Xiang, Z. Luo, N. Ruderman, Free fatty acids produce insulin resistance and activate the proinflammatory nuclear factor-kb pathway in rat liver, Diabetes. 54 (2005) 3458-3465. https://doi.org/10.2337/diabetes.54.12.3458.

[109] H. Liang, P. Tantiwong, A. Sriwijitkamol, K. Shanmugasundaram, S. Mohan, S. Espinoza, R.A. Defronzo, J.J. Dubé, N. Musi, Effect of a sustained reduction in plasma free fatty acid concentration on insulin signalling and inflammation in skeletal muscle from human subjects, J. Physiol. 591 (2013) 2897-2909. https://doi.org/10.1113/jphysiol.2012.247510.

[110] R.R. Poitout V, Minireview: Secondary beta-cell failure in type 2 diabetes--a convergence of glucotoxicity and lipotoxicity., Endocrinology. 143 (2002) 339-42.

[111] T. Čižková, M. Štěpán, K. Dad'ová, B. Ondrůjová, L. Sontáková, E. Krauzová, M. Matouš, M. Koc, J. Gojda, J. Kračmerová, V. Štich, L. Rossmeislová, M. Šiklová, Exercise training reduces inflammation of adipose tissue in the elderly: Cross-sectional and randomized interventional trial, J. Clin. Endocrinol. Metab. 105 (2020) dgaa630. https://doi.org/10.1210/clinem/dgaa630.

[112] A. Mika, F. Macaluso, R. Barone, V. Di Felice, T. Sledzinski, Effect of exercise on fatty acid metabolism and adipokine secretion in adipose tissue, Front. Physiol. 10 (2019) 26. https://doi.org/10.3389/fphys.2019.00026.

[113] N.A. Smart, N. King, J.R. McFarlane, P.L. Graham, G. Dieberg, Effect of exercise training on liver function in adults who are overweight or exhibit fatty liver disease: a systematic review and metaanalysis, Br. J. Sports Med. 52 (2018) 834-843. https://doi.org/10.1136/bjsports-2016-096197.

[114] D.Y. Kim, S.Y. Jung, B. Do Seo, Effect of exercise intervention on changes in free fatty acid levels and metabolic risk factors in stroke patients, J. Phys. Ther. Sci. 26 (2014) 275-279. https://doi.org/10.1589/jpts.26.275.

[115] M. Hargreaves, L.L. Spriet, Skeletal muscle energy metabolism during exercise, Nat. Metab. 2 (2020) 817-828. https://doi.org/10.1038/s42255-020-0251-4.

[116] T.P.J. Solomon, J.M. Haus, C.M. Marchetti, W.C. Stanley, J.P. Kirwan, Effects of exercise training and diet on lipid kinetics during free fatty acid-induced insulin resistance in older obese humans with impaired glucose tolerance, Am. J. Physiol. - Endocrinol. Metab. 297 (2009) E552-9. https://doi.org/10.1152/ajpendo.00220.2009.

[117] H. Sell, D. Dietze-Schroeder, U. Kaiser, J. Eckel, Monocyte chemotactic protein-1 is a potential player in the negative cross-talk between adipose tissue and skeletal muscle, Endocrinology. 147 (2006) 24582467. https://doi.org/10.1210/en.2005-0969.

[118] H. Kanda, S. Tateya, Y. Tamori, K. Kotani, K.I. Hiasa, R. Kitazawa, S. Kitazawa, H. Miyachi, S. Maeda, K. Egashira, M. Kasuga, MCP-1 contributes to macrophage infiltration into adipose tissue, insulin resistance, and hepatic steatosis in obesity, J. Clin. Invest. (2006). https://doi.org/10.1172/JCI26498.

[119] L. Vella, M.K. Caldow, A.E. Larsen, D. Tassoni, P.A.D. Gatta, P. Gran, A.P. Russel, D. Cameron-Smith, 
Resistance exercise increases NF-KB activity in human skeletal muscle, Am. J. Physiol. - Regul. Integr. Comp. Physiol. 302 (2012) 667-673. https://doi.org/10.1152/ajpregu.00336.2011.

[120] P.A. Monteiro, E.Z. Campos, F.P. de Oliveira, F.P. Peres, J.C. Rosa-Neto, G.D. Pimentel, F.S. Lira, Modulation of inflammatory response arising from high-intensity intermittent and concurrent strength training in physically active males, Cytokine. 91 (2017) 104-109. https://doi.org/10.1016/j.cyto.2016.12.007.

[121] I.J.A. Evers-van Gogh, A.B. Oteng, S. Alex, N. Hamers, M. Catoire, R. Stienstra, E. Kalkhoven, S. Kersten, Muscle-specific inflammation induced by MCP-1 overexpression does not affect whole-body insulin sensitivity in mice, Diabetologia. 59 (2016) 624-633. https://doi.org/10.1007/s00125-015-3822-2.

[122] J. Ko, K. Kim, Effects of exercise and diet composition on expression of MCP-1 and oxidative stressrelated mRNA of adipose tissue in diet-induced obese mice, J. Exerc. Nutr. Biochem. 17 (2013) 181188. https://doi.org/10.5717/jenb.2013.17.4.181.

[123] G. Many, M.E. Hurtado, C. Tanner, J. Houmard, H. Gordish-Dressman, J.J. Park, G. Uwaifo, W. Kraus, J. Hagberg, E. Hoffman, Moderate-intensity aerobic training program improves insulin sensitivity and inflammatory markers in a pilot study of morbidly obese minority teens, Pediatr. Exerc. Sci. 25 (2013) 12-26. https://doi.org/10.1123/pes.25.1.12.

[124] M. Trøseid, K.T. Lappegård, T. Claudi, J.K. Damås, L. Mørkrid, R. Brendberg, T.E. Mollnes, Exercise reduces plasma levels of the chemokines MCP-1 and IL-8 in subjects with the metabolic syndrome, Eur. Heart J. 25 (2004) 349-355. https://doi.org/10.1016/j.ehj.2003.12.006.

[125] V. Wallenius, K. Wallenius, B. Ahrén, M. Rudling, H. Carlsten, S.L. Dickson, C. Ohlsson, J.O. Jansson, Interleukin-6-deficient mice develop mature-onset obesity, Nat. Med. 8 (2002) 75-79. https://doi.org/10.1038/nm0102-75.

[126] B.K. Pedersen, M. Pedersen, K.S. Krabbe, H. Bruunsgaard, V.B. Matthews, M.A. Febbraio, Role of exercise-induced brain-derived neurotrophic factor production in the regulation of energy homeostasis in mammals: Experimental Physiology-Hot Topic Review, Exp. Physiol. 94 (2009) 1153-1160. https://doi.org/10.1113/expphysiol.2009.048561.

[127] M.C.K. Severinsen, C. Schéele, B.K. Pedersen, Exercise and browning of white adipose tissue - a translational perspective, Curr. Opin. Pharmacol. (2020). https://doi.org/10.1016/j.coph.2020.04.004.

[128] N. Kawanishi, H. Yano, Y. Yokogawa, K. Suzuki, Exercise training inhibits inflammation in adipose tissue via both suppression of macrophage infiltration and acceleration of phenotypic switching from M1 to M2 macrophages in high-fat-diet-induced obese mice, Exerc. Immunol. Rev. 16 (2010) 105-118.

[129] C. Brandt, A.H. Jakobsen, H. Adser, J. Olesen, N. Iversen, J.M. Kristensen, P. Hojman, J.F.P. Wojtaszewski, J. Hidalgo, H. Pilegaard, IL-6 regulates exercise and training-induced adaptations in subcutaneous adipose tissue in mice, Acta Physiol. 205 (2012) 224-235. https://doi.org/10.1111/j.1748-1716.2011.02373.x.

[130] J.Y. Bae, Aerobic Exercise Increases Meteorin-Like Protein in Muscle and Adipose Tissue of Chronic High-Fat Diet-Induced Obese Mice, Biomed Res. Int. 2018 (2018) 2018:6283932. https://doi.org/10.1155/2018/6283932.

[131] P. Kotzbeck, A. Giordano, E. Mondini, I. Murano, I. Severi, W. Venema, M.P. Cecchini, E.E. Kershaw, G. Barbatelli, G. Haemmerle, R. Zechner, S. Cinti, Brown adipose tissue whitening leads to brown adipocyte death and adipose tissue inflammation, J. Lipid Res. 59 (2018) 784-794. https://doi.org/10.1194/jlr.M079665.

[132] L.P. Kozak, R.A. Koza, R. Anunciado-Koza, Brown fat thermogenesis and body weight regulation in mice: Relevance to humans, Int. J. Obes. (2010). https://doi.org/10.1038/ijo.2010.179.

[133] J. Moon, D. Kim, E.K. Kim, S. yeong Lee, H.S. Na, G.N. Kim, A. Lee, K.A. Jung, J.W. Choi, S.H. Park, S. Roh, M. La Cho, Brown adipose tissue ameliorates autoimmune arthritis via inhibition of Th17 cells, Sci. Rep. 10 (2020) 12374. https://doi.org/10.1038/s41598-020-68749-x.

[134] L. Dowal, P. Parameswaran, S. Phat, S. Akella, I.D. Majumdar, J. Ranjan, C. Shah, S. Mogre, K. Guntur, K. Thapa, S. Gesta, V.K. Vishnudas, N.R. Narain, R. Sarangarajan, Intrinsic Properties of Brown and White Adipocytes Have Differential Effects on Macrophage Inflammatory Responses, Mediators Inflamm. 2017 (2017) 9067049. https://doi.org/10.1155/2017/9067049.

[135] R.R. Rao, J.Z. Long, J.P. White, K.J. Svensson, J. Lou, I. Lokurkar, M.P. Jedrychowski, J.L. Ruas, C.D. Wrann, J.C. Lo, D.M. Camera, J. Lachey, S. Gygi, J. Seehra, J.A. Hawley, B.M. Spiegelman, Meteorin-like is a hormone that regulates immune-adipose interactions to increase beige fat thermogenesis, Cell. 157 (2014) 1279-1291. https://doi.org/10.1016/j.cell.2014.03.065.

[136] S. Qiu, E. Bosnyák, G. Treff, J.M. Steinacker, A.M. Nieß, K. Krüger, F.C. Mooren, M. Zügel, U. Schumann, 
Acute exercise-induced irisin release in healthy adults: Associations with training status and exercise mode, Eur. J. Sport Sci. 18 (2018) 1226-1233. https://doi.org/10.1080/17461391.2018.1478452.

[137] J.G. Knudsen, M. Murholm, A.L. Carey, R.S. Biens $\varnothing$, A.L. Basse, T.L. Allen, J. Hidalgo, B.A. Kingwell, M.A. Febbraio, J.B. Hansen, H. Pilegaard, Role of IL-6 in exercise training- and cold-induced UCP1 expression in subcutaneous white adipose tissue, PLoS One. 9 (2014) e84910. https://doi.org/10.1371/journal.pone.0084910.

[138] Y. Tanimura, W. Aoi, Y. Takanami, Y. Kawai, K. Mizushima, Y. Naito, T. Yoshikawa, Acute exercise increases fibroblast growth factor 21 in metabolic organs and circulation, Physiol. Rep. 4 (2016) e12828. https://doi.org/10.14814/phy2.12828.

[139] R. Codella, L. Luzi, I. Terruzzi, Exercise has the guts: How physical activity may positively modulate gut microbiota in chronic and immune-based diseases, Dig. Liver Dis. (2018). https://doi.org/10.1016/j.dld.2017.11.016.

[140] K. Li, A. Liu, W. Zong, L. Dai, Y. Liu, R. Luo, S. Ge, G. Dong, Moderate exercise ameliorates osteoarthritis by reducing lipopolysaccharides from gut microbiota in mice, Saudi J. Biol. Sci. 28 (2021) 40-49. https://doi.org/10.1016/j.sjbs.2020.08.027.

[141] H. Luck, S. Tsai, J. Chung, X. Clemente-Casares, M. Ghazarian, X.S. Revelo, H. Lei, C.T. Luk, S.Y. Shi, A. Surendra, J.K. Copeland, J. Ahn, D. Prescott, B.A. Rasmussen, M.H.Y. Chng, E.G. Engleman, S.E. Girardin, T.K.T. Lam, K. Croitoru, S. Dunn, D.J. Philpott, D.S. Guttman, M. Woo, S. Winer, D.A. Winer, Regulation of obesity-related insulin resistance with gut anti-inflammatory agents, Cell Metab. (2015). https://doi.org/10.1016/j.cmet.2015.03.001.

[142] S.S. Ghosh, J. Wang, P.J. Yannie, S. Ghosh, Intestinal barrier dysfunction, LPS translocation, and disease development, J. Endocr. Soc. 4 (2020) bvz039. https://doi.org/10.1210/jendso/bvz039.

[143] L. Cheru, C.F. Saylor, J. Lo, Gastrointestinal Barrier Breakdown and Adipose Tissue Inflammation, Curr. Obes. Rep. (2019). https://doi.org/10.1007/s13679-019-00332-6.

[144] C. Bleau, A.D. Karelis, D.H. St-Pierre, L. Lamontagne, Crosstalk between intestinal microbiota, adipose tissue and skeletal muscle as an early event in systemic low-grade inflammation and the development of obesity and diabetes, Diabetes. Metab. Res. Rev. (2015). https://doi.org/10.1002/dmrr.2617.

[145] M.W. Rohr, C.A. Narasimhulu, T.A. Rudeski-Rohr, S. Parthasarathy, Negative Effects of a High-Fat Diet on Intestinal Permeability: A Review, Adv. Nutr. 11 (2020) 77-91.

https://doi.org/10.1093/advances/nmz061.

[146] R. Nagpal, T.M. Newman, S. Wang, S. Jain, J.F. Lovato, H. Yadav, Obesity-Linked Gut Microbiome Dysbiosis Associated with Derangements in Gut Permeability and Intestinal Cellular Homeostasis Independent of Diet, J. Diabetes Res. 2018 (2018) 3462092. https://doi.org/10.1155/2018/3462092.

[147] L.G. Hersoug, P. Møller, S. Loft, Gut microbiota-derived lipopolysaccharide uptake and trafficking to adipose tissue: Implications for inflammation and obesity, Obes. Rev. 17 (2016) 297-312. https://doi.org/10.1111/obr.12370.

[148] L.G. Hersoug, P. Møller, S. Loft, Role of microbiota-derived lipopolysaccharide in adipose tissue inflammation, adipocyte size and pyroptosis during obesity, Nutr. Res. Rev. (2018). https://doi.org/10.1017/S0954422417000269.

[149] L.A. Velloso, F. Folli, M.J. Saad, TLR4 at the crossroads of nutrients, gut microbiota, and metabolic inflammation, Endocr. Rev. (2015). https://doi.org/10.1210/er.2014-1100.

[150] P.D. Cani, J. Amar, M.A. Iglesias, M. Poggi, C. Knauf, D. Bastelica, A.M. Neyrinck, F. Fava, K.M. Tuohy, C. Chabo, A. Waget, E. Delmée, B. Cousin, T. Sulpice, B. Chamontin, J. Ferrières, J.F. Tanti, G.R. Gibson, L. Casteilla, N.M. Delzenne, M.C. Alessi, R. Burcelin, Metabolic endotoxemia initiates obesity and insulin resistance, Diabetes. (2007). https://doi.org/10.2337/db06-1491.

[151] X.H. Chen, Y.P. Zhao, M. Xue, C.B. Ji, C.L. Gao, J.G. Zhu, D.N. Qin, C.Z. Kou, X.H. Qin, M.L. Tong, X.R. Guo, TNF- $\alpha$ induces mitochondrial dysfunction in 3T3-L1 adipocytes, Mol. Cell. Endocrinol. (2010). https://doi.org/10.1016/j.mce.2010.07.005.

[152] Y. Lin, A.H. Berg, P. Iyengar, T.K.T. Lam, A. Giacca, T.P. Combs, M.W. Rajala, X. Du, B. Rollman, W. Li, M. Hawkins, N. Barzilai, C.J. Rhodes, I.G. Fantus, M. Brownlee, P.E. Scherer, The hyperglycemia-induced inflammatory response in adipocytes: The role of reactive oxygen species, J. Biol. Chem. (2005). https://doi.org/10.1074/jbc.M411863200.

[153] B.C. Lee, J. Lee, Cellular and molecular players in adipose tissue inflammation in the development of obesity-induced insulin resistance, Biochim. Biophys. Acta - Mol. Basis Dis. (2014). https://doi.org/10.1016/j.bbadis.2013.05.017.

[154] H.P.F. Peters, W.R. De Vries, G.P. Vanberge-Henegouwen, L.M.A. Akkermans, Potential benefits and 
hazards of physical activity and exercise on the gastrointestinal tract, Gut. 48 (2001) 435-439. https://doi.org/10.1136/gut.48.3.435.

[155] S.C. Campbell, P.J. Wisniewski, M. Noji, L.R. McGuinness, M.M. Häggblom, S.A. Lightfoot, L.B. Joseph, L.J. Kerkhof, The effect of diet and exercise on intestinal integrity and microbial diversity in mice, PLoS One. 11 (2016) e0150502. https://doi.org/10.1371/journal.pone.0150502.

[156] M. Matsumoto, R. Inoue, T. Tsukahara, K. Ushida, H. Chiji, N. Matsubara, H. Hara, Voluntary running exercise alters microbiota composition and increases $\mathrm{n}$-butyrate concentration in the rat cecum, Biosci. Biotechnol. Biochem. 72 (2008) 572-576. https://doi.org/10.1271/bbb.70474.

[157] S.F. Clarke, E.F. Murphy, O. O’Sullivan, A.J. Lucey, M. Humphreys, A. Hogan, P. Hayes, M. O’Reilly, I.B. Jeffery, R. Wood-Martin, D.M. Kerins, E. Quigley, R.P. Ross, P.W. O’Toole, M.G. Molloy, E. Falvey, F. Shanahan, P.D. Cotter, Exercise and associated dietary extremes impact on gut microbial diversity, Gut. 63 (2014) 1913-1920. https://doi.org/10.1136/gutjnl-2013-306541.

[158] F.S. Lira, J.C. Rosa, G.D. Pimentel, H.A. Souza, E.C. Caperuto, L.C. Carnevali, M. Seelaender, A.R. Damaso, L.M. Oyama, M.T. De Mello, R. V. Santos, Endotoxin levels correlate positively with a sedentary lifestyle and negatively with highly trained subjects, Lipids Health Dis. 9 (2010) 82. https://doi.org/10.1186/1476-511X-9-82.

[159] M. Guevara-Cruz, A.G. Flores-López, M. Aguilar-López, M. Sánchez-Tapia, I. Medina-Vera, D. Díaz, A.R. Tovar, N. Torres, Improvement of Lipoprotein Profile and Metabolic Endotoxemia by a Lifestyle Intervention That Modifies the Gut Microbiota in Subjects With Metabolic Syndrome, J. Am. Heart Assoc. 8 (2019) e012401. https://doi.org/10.1161/JAHA.119.012401.

[160] K. Byun, Y.C. Yoo, M. Son, J. Lee, G.B. Jeong, Y.M. Park, G.H. Salekdeh, B. Lee, Advanced glycation endproducts produced systemically and by macrophages: A common contributor to inflammation and degenerative diseases, Pharmacol. Ther. (2017). https://doi.org/10.1016/j.pharmthera.2017.02.030.

[161] W.N. Sayej, P.R. Knight, W.A. Guo, B. Mullan, P.J. Ohtake, B.A. Davidson, A. Khan, R.D. Baker, S.S. Baker, Advanced Glycation End Products Induce Obesity and Hepatosteatosis in CD-1 Wild-Type Mice, Biomed Res. Int. 2016 (2016) 7867852. https://doi.org/10.1155/2016/7867852.

[162] C.Y. Chiu, R. Sen Yang, M.L. Sheu, D.C. Chan, T.H. Yang, K.S. Tsai, C.K. Chiang, S.H. Liu, Advanced glycation end-products induce skeletal muscle atrophy and dysfunction in diabetic mice via a RAGEmediated, AMPK-down-regulated, Akt pathway, J. Pathol. 238 (2016) 470-482. https://doi.org/10.1002/path.4674.

[163] T.M. Langleite, J. Jensen, F. Norheim, H.L. Gulseth, D.S. Tangen, K.J. Kolnes, A. Heck, T. Storås, G. Grøthe, M.A. Dahl, A. Kielland, T. Holen, H.J. Noreng, H.K. Stadheim, A. Bjørnerud, E.I. Johansen, B. Nellemann, K.I. Birkeland, C.A. Drevon, Insulin sensitivity, body composition and adipose depots following $12 \mathrm{w}$ combined endurance and strength training in dysglycemic and normoglycemic sedentary men, Arch. Physiol. Biochem. (2016). https://doi.org/10.1080/13813455.2016.1202985.

[164] P. Boor, P. Celec, M. Behuliak, P. Grančič, A. Kebis, M. Kukan, N. Pronayová, T. Liptaj, T. Ostendorf, K. Šebeková, Regular moderate exercise reduces advanced glycation and ameliorates early diabetic nephropathy in obese Zucker rats, Metabolism. 59 (2009) 1669-77. https://doi.org/10.1016/j.metabol.2009.05.025.

[165] S.K. Malin, S.D. Navaneethan, C.E. Fealy, A. Scelsi, H. Huang, M. Rocco, J.P. Kirwan, Exercise plus caloric restriction lowers soluble RAGE in adults with chronic kidney disease, Obes. Sci. Pract. 6 (2020) $307-$ 312. https://doi.org/10.1002/osp4.408.

[166] K.L. Rodrigues, J.P. Borges, G. de O. Lopes, E.N.G. da S. Pereira, M.F.F. Mediano, P. Farinatti, E. Tibiriça, A. Daliry, Influence of Physical Exercise on Advanced Glycation End Products Levels in Patients Living With the Human Immunodeficiency Virus, Front. Physiol. 9 (2018) 1641. https://doi.org/10.3389/fphys.2018.01641.

[167] D. Ito, P. Cao, T. Kakihana, E. Sato, C. Suda, Y. Muroya, Y. Ogawa, G. Hu, T. Ishii, O. Ito, M. Kohzuki, H. Kiyomoto, Chronic running exercise alleviates early progression of nephropathy with upregulation of nitric oxide synthases and suppression of glycation in Zucker diabetic rats, PLoS One. (2015). https://doi.org/10.1371/journal.pone.0138037. 